\title{
Reconstructing the Ditransitive Construction for Proto-Germanic: Gothic, Old English and Old Norse- Icelandic
}

\author{
Juan G. Vázquez-González \& Jóhanna Barðdal \\ University of Huelva \& Ghent University
}

\begin{abstract}
:
The semantic range of ditransitive verbs in Modern English has been at the center of linguistic attention ever since the pioneering work of Green (1974), Gropen et al. (1989) and Pinker (1989). At the same time, historical research on how the semantics of the ditransitive construction has changed over time has seriously lagged behind. In order to address this issue for the Germanic languages, the Indo-European subbranch to which Modern English belongs, we systematically investigate the narrowly defined semantic verb classes occurring in the ditransitive construction in Gothic, Old English and Old Norse-Icelandic. On the basis of data handed down from Proto-Germanic and documented in the oldest layers of the three Germanic subbranches, East, West and North Germanic, respectively, we show that the constructional range of the ditransitive construction was considerably broader in the earlier historical stages than now; several subclasses of verbs that could instantiate the ditransitive in early Germanic are infelicitous in the ditransitive construction in, for instance, Modern English. Taking the oldest surviving evidence from Germanic as point of departure, we reconstruct the ditransitive construction for an earlier proto-stage, using the formalism of Construction Grammar and incorporating narrowly defined semantic verb classes and higher level conceptual domains. We thus reconstruct the internal structure of the ditransitive construction in Proto-Germanic, including different levels of schematicity.
\end{abstract}

Keywords: Early Germanic, Gothic, Old English, Old Norse-Icelandic, ditransitives, lexical semantic verb classes, syntactic reconstruction, Construction Grammar

\section{Introduction}

The abundance of work carried out on the ditransitive construction within the Germanic language family has to a large degree focused on the modern languages, with studies on Modern English clearly outshining studies on the other modern Germanic languages. Research on the ditransitive construction in Modern English has run parallel with developments in linguistic theory during the last 40 years or so, covering coercion into the dative construction and rule-based language acquisition (Pinker 1989), alternations (Levin 1993), different constructional approaches (Goldberg 1995, 2006, Croft 2003) and corpus

\footnotetext{
For comments and discussions, we thank Laura Bruno, Eleonora Cattafi, Peter Alexander Kerkhof, Svetlana Kleyner, Esther Le Mair, Roland Pooth, two reviewers of FLH and the audiences in Ghent (2015) and Zurich (2017) where earlier versions of this work were presented. For the genesis of this work, we would also like to acknowledge the role played by the 2014 International Symposium on Verbs, Clauses and Constructions (University of La Rioja), organized by Javier Martín-Arista. This research was supported with two generous research grants, the first to Jóhanna Barðdal (PI) from the European Research Council (EVALISA, grant nr. 313461) and the second to Javier Martín-Arista (grant nr. FFI2014-59110, Semántica léxica del inglés antiguo: clases verbales, alternancias y construcciones).
} 
linguistics applications like collostructional analysis (Stefanowitsch \& Gries 2003: 227-230, Stefanowitsch 2006: 61-73).

This predominance of literature on ditransitives in Modern English also surfaces in the number of varieties of English studied, which range from Indian, New Zealand, American and Southern American English varieties (Hoffmann \& Mukherjee 2007, Bresnan \& Hay 2008, Webelhuth \& Dannenberg 2006) to British English dialects (Siewierska \& Hollmann 2007, Gerwin 2014). Although less abundant, work on the remainder of the modern Germanic language family also exists. It started with contributions on Dutch (Colleman 2002, 2006, Delorge \& Colleman 2006, Delorge \& De Clerck 2007, Colleman 2009, Cappelle 2014) and continued with a thorough analysis of Icelandic (Barðdal 2007), the Modern West Scandinavian languages (Barðdal, Kristoffersen \& Sveen 2011), and German (Meinunger 2006, Adler 2011, Proost 2014, De Vaere, De Cuypere \& Willems 2018, Kholodova et al. 2019).

In a way, this predominance of synchronic studies for Modern English over the remainder of the Germanic languages hints at the absence of historical work on ditransitives for the Germanic languages and the scarcity of contributions for other historical periods of English until relatively recently. Nevertheless, more and more historical work has seen, and is seeing, the light of day for German (Røreng 2011, Rauth 2016a, 2016b), Dutch (Colleman 2002, Geleyn 2017), and the North Germanic languages, West and East (Barðdal 2007, Barðdal, Kristoffersen \& Sveen 2011, Valdeson 2019).

Contrariwise, studies of the ditransitive in the earliest attested Germanic language, Gothic, are conspicuous by their absence. Also, for earlier stages of English, relatively recent work exists on Late Modern English (Colleman \& De Clerck 2011), Early Modern English (Rohdenburg 1995, 2007, Yáñez-Bouza 2016), Middle English (Zehentner 2016, 2018) and generally for the diachronic development from Old to Modern English (YáñezBouza \& Denison 2015). As far as we are aware, no synchronic research exists of ditransitives in Old English, except for De Cuypere's (2015a, 2015b) contributions on the variation between the ditransitive construction and its prepositional variant, involving a total of 80 lexical verbs (2015a). However, the investigation presented here accounts for the semantic scope of the ditransitive construction in Old English, irrespective of its alternation with the prepositional variant.

Our ultimate goal is to reconstruct the scope of the Ditransitive Construction for Proto-Germanic on the basis of a systematic collection of data from the earliest stages of all three Germanic subbranches, East, West and North Germanic. In terms of type frequency, the database we have compiled for this research consists of 81 types for Gothic (East Germanic), 209 types for Old English (West Germanic) and 151 types for Old NorseIcelandic (North Germanic). The reconstruction of the semantic scope is carried out on the basis of a comparison of narrowly defined verb classes across the earliest stages of the three languages (cf. Barðdal et al. 2012). As such, the aim is to further develop the semantic map proposed within typology for the ditransitive construction in Modern English (Malchukov, Haspelmath \& Comrie 2007: 51), so that it includes more fine-grained distinctions than only the central ones.

Our analysis also takes into account the constraints on the argument structure of the ditransitive construction in Modern English involving volitionality on the part of the agent and willingness by the recipient (Goldberg 1995: 143-147). Colleman \& De Clerck (2011), moreover, have shown how the semantic scope of the ditransitive construction has been diminishing from the Late Modern English period onwards and undergoing semantic specialization. They show how this construction also accommodated benefactiveness and malefactiveness to a higher degree during the Late Modern English period than during later stages of the English language. In this article, we put forward a reconstruction of the ditransitive construction in Proto-Germanic, the predecessor of the early Germanic languages, showing that the ditransitive construction was broader in scope, had a more complex argument structure and, among other aspects, incorporated beneficiaries and maleficiaries to a much greater degree than in the Modern Germanic languages. This, although not surprising from an areal Standard Average European perspective (Haspelmath 1999: 109-136), is unexpected from a modern Anglocentric viewpoint given the almost "inherent" relation between transfer and the ditransitive construction assumed for Modern English. 
After our examination of the semantic scope of the ditransitive construction in Gothic, Old English and Old Norse-Icelandic, we proceed to the syntactic reconstruction of the ditransitive for Proto-Germanic. In the field of historical syntax, it has been consistently argued for decades that syntactic reconstruction is untenable, for many different reasons, one being lack of form-meaning correspondences in syntax (Lightfoot 1979, inter alia). We maintain that verbs and their argument structure constructions are form-meaning correspondences and that the meaning of schematic argument structure constructions may be taken to be a derivative of the verbs that instantiate them (Goldberg 1995, 1997, Gries, Hampe \& Schönefeld 2005, Barðdal 2008, Barðdal et al. 2012).

For some constructions, of course, the meaning of the whole is different from the sum of the meaning of the parts, while for the ordinary intransitive, transitive and ditransitive, there is a general consensus in the CxG community that such schematic constructions are semantically compositional, i.e. semantically general in the sense that the meaning of the whole is a simple derivative of the meaning of the parts. On such an assumption, verbal meaning can indeed be used as an operationalization of the meaning component of formmeaning pairings. The same is true for the structure of the ditransitive construction: it makes up the form component of this particular form-meaning pairing. On this basis, we show below how the argument structure of ditransitives may be reconstructed for Proto-Germanic on the basis of data from the earliest documented periods of all three subbranches, West, East and North Germanic, including adapting our formalism to include different levels of schematicity.

This article is structured in the following way: In Section 2 we summarize recent work that has been carried out on the development of the ditransitive construction in earlier periods of English and Germanic, including current classifications of narrowly defined semantic verb classes. We conclude the section with an introduction of the semantic classification suggested by Barðdal, Kristoffersen \& Sveen (2011), which forms the basis for our analysis below. Section 3 contains a description of the data compilation and the conceptual domains relevant for our level of analysis. An overview of the verbs occurring in the ditransitive construction in the three early Germanic languages, Gothic, Old English and Old Norse-Icelandic, respectively, is found in Appendix. On the basis of this verb list, arranged according to language and semantic subclass, in Section 4, we provide examples of a subset of the documented occurrences in the ditransitive construction in each of the three early Germanic languages. In Section 5 we propose a model of the typological scope and semantic structure of the ditransitive construction in Proto-Germanic, based on the evidence from the three daughter branches in the Appendix. We also lay out the different levels of schematicity of the ditransitive construction in Proto-Germanic, according to our proposed lexicality-schematicity network. In section 6 we proceed to the syntactic reconstruction. There, we show how the Construction Grammar formalism, recently used to reconstruct syntax, in particular, and grammar, in general, may be extended to encompass syntactic constructions which must be assumed to have existed at different levels of schematicity in the minds of Proto-Germanic speakers. Section 7 summarizes the contents and the conclusions of this work.

\section{Earlier Research on the History of the Ditransitive Construction in Germanic}

During the last decades, the bulk of the work carried out on the ditransitive construction in English and the Germanic languages has been focused on a comparison with its well-known alternant, the dative to-construction, instead of investigating the ditransitive construction on its own merit, its meaning, structure, lexical inventory, as well as its case frames in the languages exhibiting case marking, as has been the focus of research within CxG. Marking the inception of this research is Pinker's (1989: 110-123) famous analysis of verbs that can alternate between the two constructions. Pinker posits the following nine semantic verb classes for these (cf. Gropen et al. 1989, Levin 1993, Croft 2003):

1. Verbs that inherently signify acts of giving: give, pass, hand, sell, trade, lend, serve, feed, etc. 
2. Verbs of instantaneous causation of ballistic motion: throw, toss, flip, slap, poke, fling, shoot, blast ...

3. Verbs of sending: send, mail, ship ...

4. Verbs of continuous causation of accompanied motion in a deictically specified direction: bring, take ...

5. Verbs of future having: offer, promise, bequeath, leave, refer, forward, allocate, guarantee...

6. Verbs of communicated message: tell, show, ask, teach, pose, write, spin, read, quote, cite ...

7. Verbs of instrument of communication: radio, email, telephone, fax ...

8. Verbs of creation: bake, make, build, cook, sew, knit ...

9. Verbs of obtaining: get, buy, find, win, earn, grab ...

Pinker views the verbs in subclass 1 and 3 as being the most central ditransitive types, with the difference between the two subclasses lying in the means of the transfer involved: while the verbs in 3 specify means of sending, the ones in 1 are underspecified in this respect. In general, Pinker proposes an analysis of the relations among the various classes of ditransitive verbs in terms of a thematic cognitive core expressing a change of possession, exhibiting different (metaphorical) extensions into benefaction and malefaction.

While Pinker's approach is ultimately rule-based, Goldberg's (1995: 31-39) proposal is instead based on constructional polysemy. That is, Goldberg assumes a family of closely related senses springing from a basic one which expresses the actual successful transfer of an object to a recipient in the literal non-metaphorical domain. Building on Pinker (1989: 110-123) and Green (1974) among others, Goldberg (1995: 38) proposes a structure of the senses of the Ditransitive Construction in English as in Figure 1.

\title{
E. AGENT ENABLES RECIPIENT TO RECEIVE PATIENT
}

7. Verbs of permission: permit, allow

\begin{abstract}
F. AGENT INTENDS TO CAUSE RECIPIENT TO RECEIVE PATIENT

8. Verbs involved in scenes of creation: bake, make, build, cook, sew, knit

9. Verbs of obtaining: get, grab, win, earn

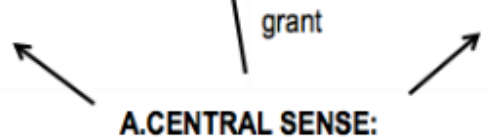

D. AGENT ACTS TO CAUSE RECIPIENT TO RECEIVE PATIENT AT SOME FUTURE POINT IN TIME

6. Verbs of future transfer: leave, bequeath, allocate, reserve, grant

A.CENTRAL SENSE:

AGENT SUCCESSFULLY CAUSES RECIPIENT TO RECEIVE PATIENT

1. Verbs that inherently signify acts of giving: give, pass, hand, serve, feed ...

2. Verbs of instantaneous causation of ballistic motion: throw, toss, slap, kick, poke, fling, shoot ...

3. Verbs of continuous causation in a deictically specified direction: bring, take
\end{abstract}

\section{B. CONDITIONS OF SATISFACTION IMPLY THAT AGENT CAUSES RECIPIENT TO RECEIVE PATIENT}

4. Verbs of giving with associated satisfaction conditions: guarantee, promise, owe

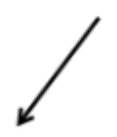

C. AGENT CAUSES RECIPIENT NOT TO RECEIVE PATIENT

5. Verbs of refusal: refuse, deny

Figure 1: Polysemy of the ditransitive construction (Goldberg 1995: 38)

The central sense postulated for the ditransitive construction, i.e. actual physical transfer (A.1), acts as the core of the prototype with instantaneous ballistic causation (A.2) and continuous causation (A.3) being further elaborations of the core sense. The remaining senses stretch from actual physical transfer to future (D) and intended transfer (F), among others. Additionally, verbs of communication express obligation (B) or the explicit negation of 
transfer $(\mathrm{C})$ and verbs of enabling $(\mathrm{E})$ profile the facilitation of the transfer on the part of the agent.

In one sense, Goldberg's constructional polysemy zooms in synchronically on what linguistic typology approaches areally and from a necessarily larger perspective. Malchukov, Haspelmath \& Comrie's (2010: 1-8) threefold definition of ditransitivity - with agent, recipient-like and theme arguments irrespective of the form in which they appear - not only allows for full case-frame analysis, but also makes room for the prepositional alternant and other possible syntactic patterns. Basing themselves upon Newman's (1996) semantic map for recipient and related functions, they propose a representation as in Figure 2.

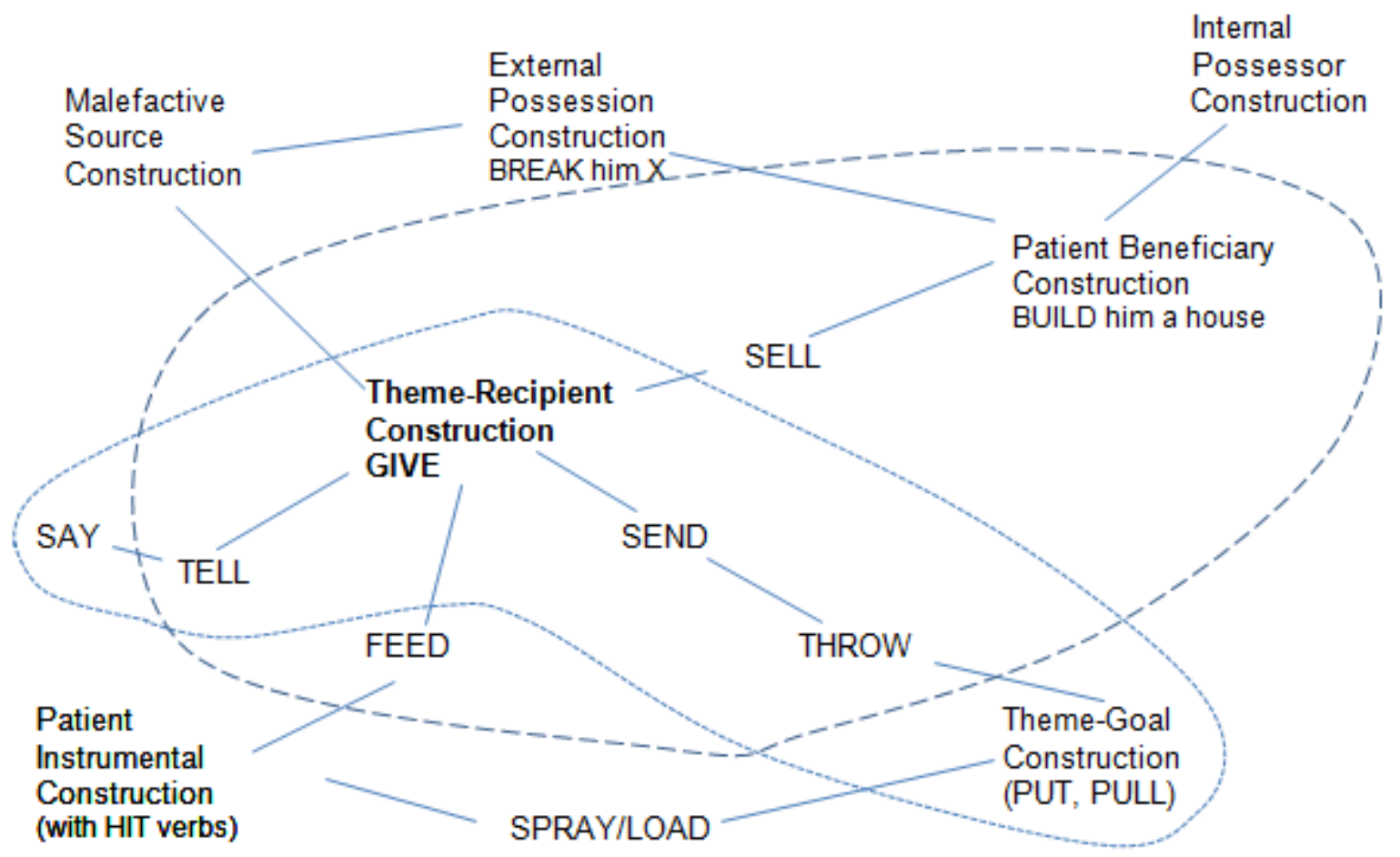

Figure 2: A semantic map of English ditransitive constructions (Malchukov, Haspelmath \& Comrie 2007: 51).

Malchukov, Haspelmath \& Comrie (2007: 51) suggest a cline from recipient to beneficiary and on to possessor and another from recipient to malefactive. This is shown with intermediate lines connecting these semantic roles on the map in Figure 2. The recipient role also links with goal to specify the transition from change of possession to change of location, the two existing central ditransitive classes, according to their analysis, again shown with intermediate lines. Malchukov, Haspelmath \& Comrie nevertheless acknowledge that the verb types included are but a selection and that there may be further unidentified connections to be found on the map. Their semantic map in Figure 2 further demarcates the differences between the ditransitive construction in Modern English and its prepositional variant, yielding the ditransitive construction with dashed lines, its prepositional variant with dotted lines and profiling the shared alternational space. Benefactives are included in their proposal and exemplified by means of build (verbs of creation, class 8 in Pinker and Goldberg).

According to Malchukov, Haspelmath \& Comrie (2007: 53), semantic maps are not only useful for areal variation, but have also proven valid for diachronic studies (cf. Barðdal 2004, 2007, Haspelmath 2004, Luján 2010, Narrog 2010, Narrog \& Van der Auwera 2011, Grossman \& Polis 2012, Luraghi 2014). In Section 5, we make use of Malchukov, Haspelmath \& Comrie's semantic map proposal, adapting it for the visual layout of the semantic range of the ditransitive construction in early Germanic, as revealed by the 
comparison in sections 3.2 and 4 . We focus on the role of constructional change in order to account for the differences between Proto-Germanic and early Germanic, on the one hand, and Modern English, on the other.

Barðdal's (2007) constructional analysis breaks away from an exclusively anglocentric perspective by studying the lexical and semantic range of the ditransitive construction in Modern Icelandic and by validating the results obtained for Modern Icelandic in North Germanic, i.e. Norwegian and Swedish dialects in particular. Barðdal (2007: 11-13) specifies the following 17 narrowly defined semantic verb classes for Modern Icelandic:

1. Verbs denoting (prolonged) possession/owning: eiga sér e-ð to have sth for yourself', etc.

2. Verbs inherently denoting giving or delivering: gefa e- $m$ e-ð 'to give sb sth', selja $e-m$ e- $\delta$ 'to sell sb sth', etc.

3. Verbs of lending: lána e-m e-ð 'to lend sb sth', etc.

4. Verbs of paying: borga e-m e-ð 'to pay sb sth', etc.

5. Verbs of sending: senda e-m e-ठ 'to send sb sth', etc.

6. Verbs of bringing: bera e-m e- $\circlearrowright$ 'to bring sb sth', etc.

7. Verbs of future transfer: bjóđa e- $m$ e-ð 'to offer sb sth', etc.

8. Verbs denoting transfer along a path: opna e-m leið to open up a passage/door for sb', etc.

9. Verbs of enabling: auðvelda e- $m$ e-ð 'to facilitate sth for sb', etc.

10. Verbs of communicated message: kynna e-m e- $ठ$ 'to introduce sth to sb', etc.

11. Verbs of instrument of communicated message: (e)meila e-m e- $ठ$ 'to (e)mail sb sth', etc.

12. Verbs of creation: byggja sér e-ð 'to build oneself sth', etc.

13. Verbs of obtaining: ávinna sér e- $ठ$ 'to acquire sth for oneself', etc.

14. Verbs of utilizing: nýta sér e- $ठ$ 'to make use of sth', etc.

15. Verbs of hindrance: banna e-m e- $ठ$ 'to forbid sb (to do) sth', etc.

16. Verbs of constraining: setja sér e- $ठ$ 'to determine to do sth', etc.

17. Verbs denoting mental activity: fyrirgefa e-m e-ð 'to forgive sb sth', hugsa sér e-ð 'to think of sth', etc.

As Barðdal's analysis shows, several of the North-Germanic subconstructions are missing from Modern English, namely possession (1), transfer along a path (8), utilizing (14), hindrance (15), constraining (16) and mental activity (17). In contrast, instantaneous causation of ballistic motion (class 2 above) is missing from Modern Icelandic. Barðdal also demonstrates that verbs of ballistic motion are absent from North Germanic with the only exception of a Swedish dialect, Överkalix, where these verbs must be a late innovation. Verbs of stealing/robbing do not occur in the oldest North-Germanic layers with a Dat-Acc case frame, hence they are not included here (see however Barðdal, Kristoffersen \& Sveen 2011 for an analysis involving these verb classes). As the other modern North Germanic varieties and Old Norse-Icelandic display a very similar list of subconstructions, Barðdal (2007: 27) proposes a semantic map for (Proto-)Germanic, as in Figure 3.

Conceptual affinity is portrayed by contiguity in the semantic map in Figure 3; between Creation and Obtaining; Utilizing and Owning; Enabling, Hindrance and Constraining (these three specify power or authority); between Sending, Instrument of communication and Communicated message; or finally between Communicated message and Mental activity. Comparing Modern English and historical North Germanic, verbs of Ballistic motion are missing, as stated above, and the same is true for verbs of Instrument of communication. The latter, with verbs like radio, telephone, fax, email, text, etc (class 7 in Pinker above), are ruled out as they specify modern world inventions.

The map in Figure 3 is a reconstruction of a potential semantic space for the ditransitive construction in Proto-Germanic, based on verb classes in Old Norse-Icelandic and the modern Germanic languages. Our aim here is to take this reconstruction even further, based on correspondence sets from the earliest documented Germanic layers, i.e. Gothic, Old English and Old Norse Icelandic. Hence, in Section 6 below, we employ a CxG formalism for syntactic reconstruction, as opposed to the semantic reconstruction found in Barðdal (2007). 


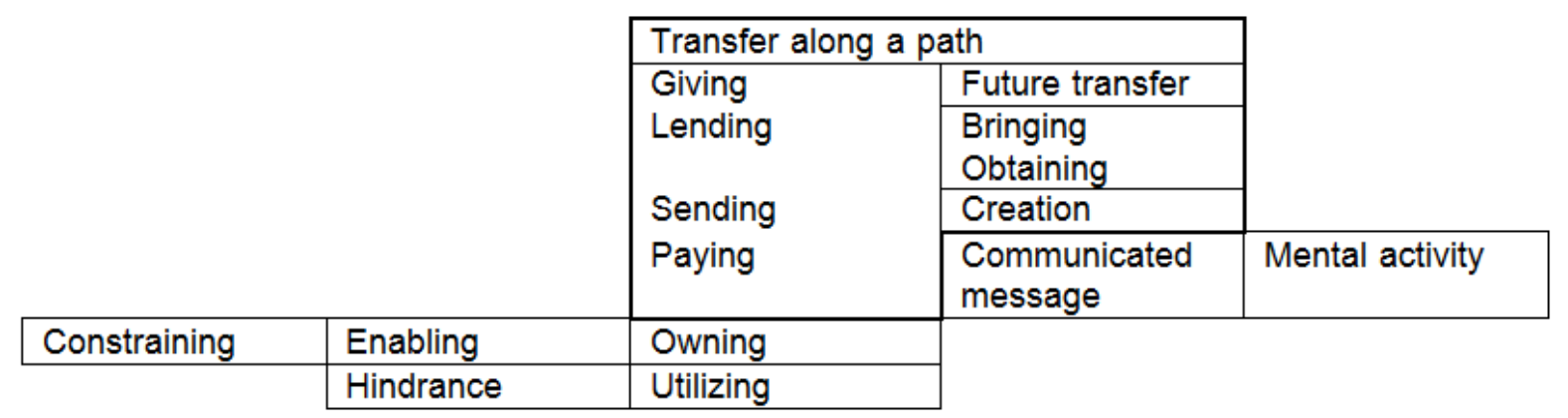

Figure 3: A semantic map of the ditransitive DAT-ACC construction in (Proto-)Germanic.

As already mentioned in Section 1 above, Colleman \& De Clerck (2011) are the first, as far as we are aware, to bring the diachrony of the English ditransitive construction to the fore within a constructional framework; using a corpus of 18th century Late Modern English (De Smet 2005), they show that the constructional semantics displayed by the English Ditransitive Construction during that period is richer and more complex than in present-day English. Colleman \& De Clerck summarize their corpus results as in Table 1.

Table 1: Present-day subconstructions of the ditransitive and their representatives in the 18th century (Colleman \& De Clerck 2011: 191)

\begin{tabular}{ll}
\hline Verb class & $\begin{array}{l}\text { Class members attested in the DOC } \\
\text { in the } 18^{\text {th }} \text {-century data }\end{array}$ \\
\hline Verbs which inherently signify acts of giving & give, lend, pay, sell, return, allot, \\
& grant, reach, deliver, assign, remit, ... \\
Verbs of instantaneous causation of ballistic motion & throw \\
Verbs of continuous causation of accompanied motion & bring, carry, drag \\
Verbs of sending & send \\
Verbs of giving with associated satisfaction & offer, owe, promise, reserve, assure, \\
conditions/Nerbs of future transfer & $\ldots$ \\
Verbs of permission & allow, permit \\
Verbs of refusal/Verbs of future not having & deny, refuse, save, spare, cost \\
Verbs of type of communicated message (i.e. verbs of & tell, ask, teach, show, write, \\
telling, teaching and showing) & recommend, read, inform, answer ... \\
Verbs of instrument of communication & $I$ \\
Verbs of creation/preparation & make, prepare, fill (a glass), design, \\
& $\ldots$ \\
Verbs of obtaining & get, buy, fetch, find, leave, obtain, ... \\
Verbs of performance & sing, play \\
Verbs concerned with feelings and attitudes & envy, forgive, grudge, intend \\
\hline
\end{tabular}

The range of subconstructions in 18th century English already anticipates the current state of affairs. For instance, verbs of instrument of communication (fax, email, radio, etc.) are self-evidently absent from Table 1 . However, Colleman \& De Clerck convincingly show that the range of the ditransitive construction was broader in terms of verb classes and usages in 18th century English than in Modern English. First, and in consonance with Rohdenburg's (1995, 2007) findings, Colleman \& De Clerck validate the existence of verbs of banishment (banish, dismiss, expel) in their late Modern English corpus. Second, they bring to light the presence of benefactive examples like "the young Benedictine holding him the torch as he wrote" (2011: 195), malefactive instances with spoil (2011: 197), i.e. with verbs of dispossession (cf. also Zehentner 2018 on Middle English). Third, they also document the existence of manner of speaking terms, like whisper, that can no longer operate on a ditransitive basis (for Old English, see De Cuypere 2015a-b). 
Finally, Barðdal, Kristoffersen \& Sveen (2011: 66-70) find additional evidence in West Scandinavian, specifically in Modern Faroese and Norwegian, for the existence of the 17 semantic verb classes proposed for Icelandic by Barðdal (2007). They expand on Croft's (2003) concept of lexicality-schematicity hierarchies by going beyond the 17 narrowly circumscribed verb classes to positing eight higher-level semantic categories. The proposed integration of the 17 semantic verb classes into eight broader, more general semantic categories of ditransitives is shown in the semantic map in Figure 4.

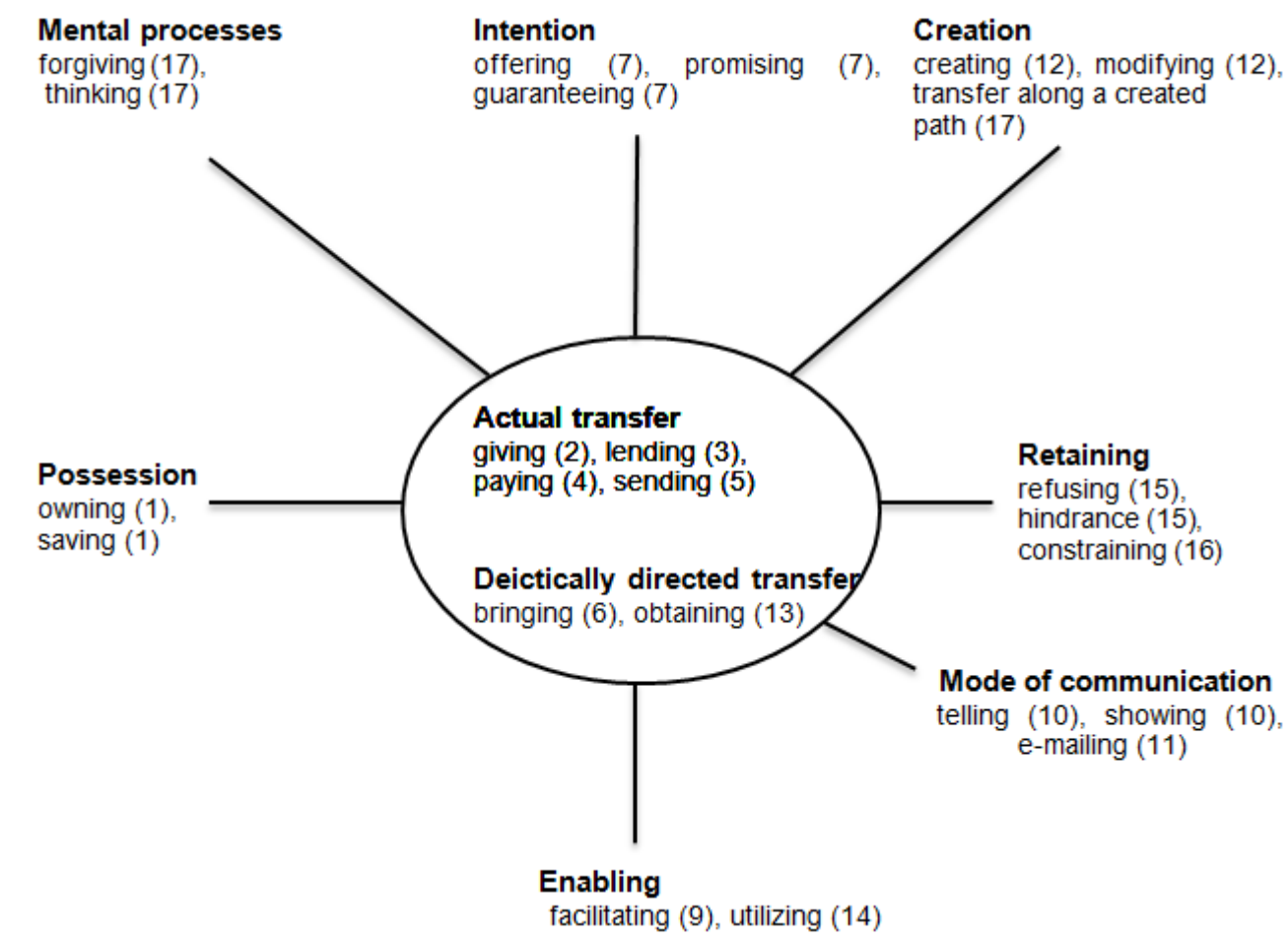

Figure 4: The semantics of the ditransitive construction in Icelandic (Barðdal, Kristoffersen \& Sveen 2011: 64)

There is a general consensus in the literature on the ditransitive construction that actual transfer and the transfer schema form the core of this category (Pinker 1989: 113; Goldberg 1995: 32-39), with verbs of giving (1) and sending (2) being the most general and lending (3) and paying (4) being more specific. Together with sending (5), verbs of bringing (6) and obtaining (13) are also included as these also specify a deictic reading of the transfer schema. Intention is not exclusively restricted to the concept of transfer, epitomized in offering (7), but it also incorporates terms related to Goldberg's "conditions of satisfaction" like promise or guarantee. Under Creation, two other verb classes are found, modifying (12), where the focus is on the preparation of an object, and transfer along a created path (17), where it is only through an incremental creation that the actual transfer takes place. Mode of communication consists of verbs of communicated message (telling, showing 10) and of instrument of communication (e-mailing 11). The scope of Enabling expresses assistance and advantage in general (facilitating 9, utilizing 14) and Retaining integrates hindrance (15) and constraining (16) with a subclass like refusing (15). Mental processes comprise pure mental activity (thinking 17) and metaphorical transfer of mental attitudes (forgiving 17). Finally, (prolonged) Possession materializes in Modern Icelandic by terms like owning and saving (1), and are constrained to a reflexive object.

Barðdal, Kristoffersen \& Sveen (2011: 70-76) also bear out these findings in Old Norse-Icelandic; they ascertain that the lack of transfer along a path in Old Norse-Icelandic must be due to a gap in the historical texts preserved, as they find evidence for this semantic verb class in Danish, Swedish and even German, involving cognate lexical material. Given that, the only difference between Old West Scandinavian and Modern West Scandinavian 
lies in the absence of verbs of instrument of communication in Old Norse-Old Icelandic, like (e)meila e-m e-ð, 'e-mail sb sth'.

We now turn to Section 3, where we present necessary definitions, report on our data compilation and give an overview of the relevant conceptual domains in which the ditransitive verbs in Gothic, Old English and Old Norse-Icelandic are situated. We closely follow the proposal of Barðdal, Kristoffersen \& Sveen (2011: 63-66) although we assume nine conceptual domains, instead of their eight, within which the narrowly defined 17 verbspecific classes belong, with some amendments where specified. The difference between the present proposal and Barðdal, Kristoffersen \& Sveen's (2011) is that we have split up Actual Transfer into Deictically Specified Transfer and Giving/Delivering, since each of these contain several different verb classes.

\section{Definitions, Data Compilation and Conceptual Domains}

We start this section with a morphosyntactic definition of the ditransitive construction and a description of how the data from Gothic, Old English and Old Norse-Icelandic were compiled (3.1). We then lay out the nine conceptual subdomains relevant for the ditransitive construction (3.2), before turning to the early Germanic data in Section 4.

\subsection{Definitions and Data Compilation}

In this article we define the ditransitive construction in morphosyntactic terms as involving a verb which selects for three arguments, a subject, a direct object and an indirect object. In other words, the verb is a three-place predicate in which the subject, object, and indirect object are all direct arguments of the verb or the construction. We confine our analysis to ditransitive verbs selecting for dative indirect objects and accusative direct objects, i.e. NomDat-Acc constructions. This case frame shows the highest type frequency in the modern West Scandinavian languages and Old Norse-Icelandic (Barðdal, Kristoffersen \& Sveen 2011), prevails over Nom-Acc-Dat in the Gothic corpus and in our selection of Old English texts, as well as being the basis for the modern English ditransitive. We have excluded the remaining subconstructions of the ditransitive construction (Nom-Acc-Dat, Nom-Acc-Gen, Nom-Dat-Gen, Nom-Dat-Dat and Nom-Acc-Acc) from the analysis for reasons of space (hence, any further use of the term ditransitive construction below refers to Nom-Dat-Acc only). To illustrate the Nom-Dat-Acc frame, consider the examples from Modern English in (1) below, retrieved from the World Wide Web, where the indirect object is italicized and the direct object is boldfaced:

(1a) God gave me you.

(1b) And you forgave me my dirty little past?

(1c) Her sister did her a favor by destroying Grandmother's Wedding Dress!!!

(1d) His brothers meant him evil ...

We have made only one exception to our formal definition of ditransitives above as explicating the Nom-Dat-Acc frame, and that applies to the Gothic verb, (be)swaran, with which the Acc was realized as an object clause and not as a direct object. However, due to the limited size of the Gothic corpus and the high quality of the comparative evidence, i.e. the existence of accusative direct objects in Old English and Old Norse-Icelandic with these same verbs, we take it that Nom-Dat-Acc was also used with these verbs in the Gothic language.

In accordance with a constructional analysis, we regard the ditransitive construction as a form-meaning correspondence. We take the meaning of the construction to be derived from the meaning of the verbs instantiating it (cf. Goldberg 1995, Barðdal 2006, 2008). An analysis of the verbs and verb classes which define the Ditransitive Construction in Early Germanic is found in Appendix. 
With regard to data compilation, the Old Norse-Icelandic examples were collected using a selection of text corpora (Barðdal 2007: 10, 18-20) and the electronic version of Fritzner's Old Norse dictionary Ordbog over det gamle norske Sprog (Barðdal, Kristoffersen \& Sveen 2011: 70-76). The data obtained were then juxtaposed with the inventory of Old Norse-Icelandic verbs in Cleasby \& Vigfusson (1959: xxxv-xli). The Gothic examples were extracted from the linguistically annotated Gothic corpus on the Wulfila Project homepage (http://www.wulfila.be). This project has produced a lemmatized and fully tagged online edition of Streitberg's (1960 [1919]) Bible containing the fragments of the Gospels, the epistles and some minor texts. This linguistically annotated text corpus allows for case disambiguation, only one click away from the user. We searched for instances of verbs appearing in the Nom-Dat-Acc case frame, instances that were verified after checking the morphosyntactic information provided by the project for each of the three participants. We sometimes made use of the selected interlinear translations on display to verify our results, particularly those for Greek and Latin, which act to some extent as parallel corpora. The Gothic corpus contains a total of 81,244 words and an exhaustive search resulted in 81 types.

The Old English examples were extracted from Skeat's edition of The Anglo-Saxon Gospels in Anglo-Saxon, Northumbrian and Mercian versions (Vázquez-González 2013, 2014). The translations of the Gospels into Old English acted as a parallel corpus for the Gospels in Gothic but, contrary to the situation in Gothic, the Old English versions have been preserved in their entirety, amounting to 79,193 words. Since the Gothic corpus also contains non-Gospels texts (38,989 words), we incorporated the translations of the Book of Genesis and Exodus into our Old English text selection (42,747 words). The Gospels chosen cover different varieties of early Old English texts, dated no later than the end of the 9th century. The Genesis and Exodus are late West Saxon texts associated with the Old English Hexateuch and ÆElfric. In the end, our Old English text selection amounted to 121,940 words, almost a third in size when compared to the Old English section of the Helsinki Corpus. After manually reading through the texts, we obtained a total of 104 types in this first phase of data gathering.

During a second phase, the data obtained for each daughter language was systematically cross-checked for cognates occurring in the ditransitive construction in the other two languages by means of etymological dictionaries (Pokorny 1959-1969, Kroonen 2013). This led further to extensive use of resources like The Dictionary of Old English Corpus and the available dictionary entries (Healey et al. 2000 and 2009), the digital edition of Bosworth \& Toller's (1921) Anglo-Saxon Dictionary and Fritzner's (1886-1896) cited dictionary of Old Norse-Icelandic, where further types have been uncovered. At the end of the process of data compilation, the types for Old Norse-Icelandic and Old English had increased to 151 and 209, respectively, to be combined with the 81 Gothic types in a final database of ditransitive verbs for the three daughter languages involved (Barðdal \& Vázquez-González 2015). Since the data for Old Norse-Icelandic have to a large degree been retrieved through dictionary searches (cf. Barðdal 2007, Barðdal, Kristoffersen \& Sveen 2011), we refrain from compiling any text or token frequencies for the three early Germanic languages under investigation.

The validation of verb types in the Gothic corpus and our selection of Old English texts is bottom-up: after finding a ditransitive usage, we proceeded to verify it by checking the related dictionary definitions and entries, as many dictionary entries already define lexical units in ditransitive terms. This is particularly true of Old Norse-Icelandic lexicography, past and present (cf. Fritzner 1886-1896 and several modern Icelandic dictionaries), but also holds for the available entries from the Dictionary of Old English (Healey et al. 2009). For instance, in the display of sense (3a) for Old English areccan, the telling of something (acc) to someone (dat), follows the basic meaning definition 'to recount, tell'. In those cases in which we have followed traditional works like Bosworth \& Toller (1929), it is more usual to find brief meaning definitions, sometimes mere glosses, which is why we have always verified the ditransitivity of a given verb type by finding another quotation among the ones available in the related sense section.

Concerning our criteria for category membership, the units in each of the listed domains have been classified together according to their similarity in meaning. For instance, the notion of preparing something for someone matches with Gothic manwjan, Old English 
gearwian and Old Norse-Icelandic göra. These verbs and a few others with similar interpretation have been labelled as verbs of preparation, a verb-subclass-specific construction ascribed to the domain of Creation. This bottom-up procedure, based on semantic similarity, seems straightforward enough but is sometimes made difficult because of the conceptual affinities shown by different verbs. In this respect, we fully subscribe to Barðdal's (2007) comments on the overlapping existing between Creation and Possession specifically, verbs of obtaining - when the ditransitive usage is also reflexive, an overlap which applies to Gothic and Old English as well. In Old Norse-Icelandic, afsegja sér e-t 'to resign, renounce', which is a speech act verb, hence belonging to Mode of Communication, bears obvious connections with verbs of dispossession like afsitja sér e-t 'to alienate from one's family' and Gothic afslaupjan 'to clip off, put off'. Different senses of each verb are treated here as separate types. For instance, sellan and gesellan in Old English could both mean 'give, hand over' (glossed by Latin dare) and 'donate' (Latin donare). On our approach verbal meanings like 'give, hand over' belong to verbs of Giving, while the 'donate' sense relates to verbs of conferring, within the larger conceptual domain of Enabling. A similar distinction also holds for Gothic giban, for instance. In this respect, we have availed ourselves of dictionary entries when establishing criteria for distinguishing between different verb senses. We have also verified dictionary definitions for specific examples of this study. For instance, Gothic galewjan is defined in Köbler's Gotisches Wörterbuch (1989) as 'hand someone over in an opportunistic deal, give over, betray'. Whereas this verb appears twice with the meaning(s) described, the instance that we have included in our database refers to the Christian notion of offering (someone) the other cheek, is glossed by Latin praebeo and has accordingly been categorized as part of Intention.

Moreover, in some cases, the meaning of the whole is not derivable from the meaning of the parts, but either from the meaning of the verb together with the direct object or simply noncompositionally in that the meaning of the whole is different from the meaning of the parts. In this respect, the types selected range lexically from isolated units like Old English beodan 'to offer' and prefixed terms like Gothic atbairan 'bring, lead' to verb + direct object combinations like Old Norse-Icelandic skipa stað 'to give property' and more complex idiomatic structures like fá e-m e-t at geyma 'to give into one's charge'. Since these show distinct meanings, each of these units qualifies as a type of its own even in those cases in which two or more types seem have the same phonological string or in cases where one seems to be a derivative of the other. For example, in Old Norse-Icelandic the idiomatic collocation velja e-m hæðilig orð 'to speak ignominiously to (or of) one' has a different meaning than the simple velja, which means 'choose'. Accordingly, these two count as two different types in our investigation. We acknowledge here that there may be an imbalance between Old Norse-Icelandic, on the one hand, and Old English and Gothic, on the other, due to the fact that the lexicography of Old Norse-Icelandic has favored these more complex types even in traditional works such as Cleasby \& Vigfusson (1957).

A similar situation also holds for reflexive ditransitives in the lexicography of the three languages: while these are frequently documented in regular Old Norse-Icelandic dictionary entries, they are not so commonly found in Gothic, which unfortunately displays a rather restricted corpus in terms of size. Reflexive transitives have also been largely absent from Old English lexicography until relatively recently. Contrary to non-reflexive ditransitives, reflexives may develop a special semantics of their own (see, for instance, the Norwegian $\mathrm{V}$ REFL-NP construction å ta seg en øl 'to treat oneself to a beer', and similar examples from other related languages, cf. Barðdal, Kristoffersen \& Sveen 2011: 82-99). With respect to the lexicographical shortcomings specified above, we have not performed a systematic contrastive analysis of these patterns and the role that they might play within a larger, more comprehensive ditransitive space, as this lies beyond the scope of this work. Nevertheless, we have incorporated specific constructions like Old Norse-Icelandic eiga sér e-t to possess something for yourself' and the corresponding Old English reflexive use of agan into our verb lists, treating them as specific types also.

We now turn to the conceptual domains of relevance for the present study. 


\subsection{Conceptual Domains}

We propose nine higher-level constructional categories for Proto-Germanic (numbers in brackets below refer to the verb classification in Barðdal, Kristoffersen \& Sveen 2011, which in turn is based on Barðdal's 2007 analysis): verbs of Giving and Delivering (1), Enabling (2), Deictically directed transfer (3), Intention (4), Creation and Miscreation (5), Possession and Dispossession (6), Retaining (7), Mode of Communication (8) and Mental Processes (9). There is no doubt that the links between these nine conceptual domains are diverse and complex and what follows is a simplification for the sake of convenience.

Actual transfer where an object is moved from one participant to another, is the prototype for the transfer schema, found in Giving (1), Enabling (2) and Deictically specified transfer (3) mainly, but also being partly relevant for others like Retaining (7), for instance. Intended transfer (4) is found with verbs of obtaining, which are here classified under Possession (6), hence profiling the initial or the endpoint of the transfer event. Metaphorical transfer applies to Mode of Communication (8), but is also valid for Mental Processes (9). Transfer may also be conceptualized as being benefactive for a participant, as with Creation (5). Alternatively, the opposite of benefactive, namely malefactive transfer appears with Miscreation (5), Dispossession (6) and partly with Retaining (7). These malefactive domains involve verbs with a high degree of (negative) affectedness. Finally, lack of transfer is found particularly in Miscreation (5) but also to some extent with verbs of Retaining (7) and Possession (6).

These nine higher-level conceptual domains are further outlined below:

\subsubsection{Verbs inherently signifying giving or delivering}

As in Modern English, verbs inherently signifying giving or delivering self-evidently make up the core of the conceptual domain of giving, where we find the prototype 'give' (cf. Kittilä's 2006 prototype approach to ditransitivity with 'give' as its most central member): Gothic giban, OE sellan and Old Norse-Icelandic selja and gefa. This conceptual domain also includes verbs of entrusting and verbs of giving back (4), as in returning, paying and selling. In addition, we have identified a further subclass, namely verbs of distributing, which has not been discussed in the earlier literature.

\subsubsection{Enabling}

This higher-level conceptual domain includes verb classes like conferring (7), lending (3), letting and allowing (7), which all involve a difference in authority between the agent and the recipient in that the agent facilitates transfer to the recipient. Verbs portraying granting or donating (giban, giefan, gefa, etc.) are a subcategory of conferring. Verbs of utilizing (14) are left out, since such examples only exist in Old Norse-Icelandic, but are not found in Gothic and Old English. Our analysis also differs from the analysis presented in Goldberg (1995: 38-39), where verbs like granting are classified as verbs of future transfer.

\subsubsection{Deictically directed transfer}

In this conceptual domain, the passing of an object from one participant to another brings about a change of location. This applies to bringing (5) and sending (6), which include many verbs which specify the two poles of the transfer schema, the starting point and the endpoint. The verbs involved are closely linked to both change of location and change of possession.

\subsubsection{Intention}

This conceptual domain contains verbs either expressing intention in general or intended transfer. This means that actual transfer is implied with some verbs but it is not a prerequisite for ascription to this higher-level conceptual domain. Hence, the conceptual domain of intention comprises verbs of future transfer like leave or offer (class 7 above) and "verbs of giving with associated satisfaction conditions" such as promise, guarantee or owe (Goldberg 1995: 38). These two lower-level verb classes are relatively well attested in the three cognate languages involved. 


\subsubsection{Creation and Miscreation}

Three different subclasses have been identified as belonging to the conceptual domain of creation (12). The first subclass of verbs are that of creating, like in OE cennan menn sunu 'to beget a child for sb, where an object is literally made, generated or given shape. A related subclass implies the modification or preparation of an object (12), like with the Old NorseIcelandic predicate gera e- $m$ reiðskjót 'to prepare a horse for sb', given the assumption that modification is a form of creating. The third subclass includes verbs conveying transfer along a path (17), where the path is incrementally created during the verbal event. As its corollary, we have also identified verbs involving miscreation and blocking of a path.

\subsubsection{Possession (obtaining) and Dispossession}

This conceptual domain is divided into verbs of owning (1), obtaining (13) and, consequently, disowning. We consider obtaining to be an extension of owning, involving its inception, see for instance stative-inchoative pairs like Old English agan agnian and Old Norse-Icelandic eiga eigna, which both mean 'own' and 'come into ownership of', respectively. The concept of obtaining also ranges from taking, seizing or getting (Gothic niman, Old Norse-Icelandic taka) to economic transactions (OE earnian 'to earn, get' and Old Norse-Icelandic kaupa 'to buy'). For disowning, we have identified verbs of removal and verbs of spoliation such as $\mathrm{OE}$ forstelan 'to steal with violence, snatch'.

\subsubsection{Retaining}

The conceptual domain of retaining is made up of verbs of hindrance (15) and constraining (16). This may involve transfer or not. When involving transfer, it may be blocked, as with Goldberg's verbs of refusal and OE geteon wearne 'to give someone a denial', or the transfer may be made difficult and/or take place eventually (Barðdal, Kristoffersen \& Sveen 2011: 65). In such cases, the transfer is conceptualized as some kind of malefactive imposition or obligation, which is true for the majority of verbs of hindrance. Moreover, verbs of constraining are often related to societal and/or cultural norms.

\subsubsection{Mode of communication}

The conceptual domain of mode of communication describes various ways of communicating, including two main verb classes, i.e., verbs of communicated message (10) and verbs of instrument of communication (11). The first subclass contains verbs like 'say', 'tell' or 'teach'. The second one focuses on instruments of communication which in the case of the medieval world mostly involves (religious) writing, rune-carving and chants or incantations.

\subsubsection{Mental processes}

Verbs belonging to the conceptual domain of mental activity (17) portray metaphorical transfer of mental attitudes, like for instance 'to bestow one's love on someone'. In other cases, a metaphorical transfer of mental states may be involved, like with 'make sth known'. Yet other verbs simply specify mental processes like 'intend' or 'realize' or even perception like 'open someone's eyes'.

\section{The Ditransitive Construction in the earliest Germanic Layers}

After having described the nine conceptual domains relevant for the semantic distribution of the ditransitive construction across the early Germanic languages, we turn to a description of the data. All the relevant verbs and their categorization into conceptual domains are listed in Appendix. Below we present our summaries of the data from Gothic, Old English and Old Norse-Icelandic, including a variety of verb classes for each conceptual subdomain introduced in Section 3.2 above and examples from each language. We pay special attention to those verb classes exhibiting differences in their argument structure from the modern Germanic languages, in particular English. 


\section{Domain 1: Verbs inherently signifying giving and delivering}

The main verbal meanings belonging to this conceptual domain are summarized in (2) below, with examples illustrating the ditransitive use for Gothic, Old English and Old NorseIcelandic, respectively:

(2) 'give, give over, deliver, present, hand, reach, betroth, entrust, commit, assign, deal out, distribute, divide, give back, give in return, pay, repay, compensate, sell'.

(2a) Gothic

(2a) duppe Moses atgaf izwis bismait.

therefore Moses gave you.DAT circumcision.ACC

(2b) Old English

'Therefore Moses gave unto you (the law of) circumcision.' (John 7:22)

... Vnderfoh pis cyld \& fed hit me, \& ic pe sylle pine

take this child and nurse it me and I.NOM you.DAT give your.ACC

mede

wages.ACC

'Take this child away, and nurse it for me, and I will give thee thy wages.'

(2c) Old Norse-Icelandic

... gjaltu mér son mínn!

compensate me.DAT son.ACC mine

'... You shall compensate me for my son!' (Heilag. I, 1767)

The core of Actual Transfer is inherent giving, which centers around prototypical verbs like Gothic giban, OE sellan ${ }^{1}$ and Old Norse-Icelandic gefa and selja, primarily. It may seem striking at first that we regard sellan ${ }^{1}$ and not giefan as the prototype in Old English. The reason is that sellan ${ }^{1}$ may mean 'to give', 'to grant', 'to entrust', 'to betroth', 'to offer', 'to deliver', 'to supply', to exchange', 'to sell', 'to pay', etc. (Bosworth \& Toller 1921: 861-862). The semantics of Old English giefan, on the other hand, are more related to conferring, bestowing, allowing or letting than to giving, and we have accordingly classified it as part of Enabling.

In Modern English, ditransitive usages with verbs of distribution are rare but exist, found with allot, allocate (cf. Levin 1993: 29) and sporadically with deal. They are, moreover, absent in the remaining Modern Germanic languages. Verbs of distribution, however, are found in the ditransitive construction in the oldest period of the three daughter languages, as shown in the following examples:

(3a) Gothic

... jah disdailida im swes sein

and divided them.DAT inheritance.ACC his.ACC

' $\ldots$ and he divided unto them his living.' (Luke 15:12)

(3b) Old English

... \& pus cwæð, hig todældon heom mine reaf

and thus said, they.NOM dealt.out them.DAT my clothes.ACC

' $\ldots$ and was thus spoken; they parted my garments among them.' (Matthew 27:35)

(3c) Old Norse-Icelandic

pú kunnir aldregi deila mönnum mat

you.NOM knew never deal men.DAT food.ACC

'You never knew how to deal food to the men.' (Lokasenna 46)

As the examples in (3) above show, the direct object that is moved from one participant to the other may be apportioned and/or distributed among several human recipients. Verbs of distributing are numerous in the three early daughter languages (see Appendix), clearly forming a subclass of their own under the conceptual domain of giving/delivering. 


\section{Domain 2: Enabling}

The main verbal meanings belonging to this conceptual domain are summarized in (4) below, with examples illustrating the ditransitive use for Gothic, Old English and Old NorseIcelandic, respectively:

(4) 'confer, grant, donate, lend, allow, let, permit, give leave, forbear, let go, set free, forgive, do a favor'

(4a) Gothic

... wileidu nu ei fraletau izwis pana piudan ludaie?

will.you now that I.release you.DAT the.ACC King.ACC Jews.GEN

(4b) Old English

'.. will ye therefore that I release unto you the King of the Jews?' (John 18:39)

Ic de selfes dom life, leofa.

I.NOM you.DAT own.GEN choice.ACC allow dear

'I allow you your choice (of land), lord.' (Genesis 1915)

(4c) Old Norse-Icelandic

Hann gaf honum vald yfir öllu landi.

he.NOM gave him.DAT authority.ACC over all land

'He gave him authority over all the land.' (Fms i. 18)

Enabling appears to be a larger conceptual domain in the three early Germanic daughters than in Modern English, forming part of Actual Transfer. Goldberg (1995: 26) discusses permit and allow and shows that this subclass is not productive in Modern English. The same can be said of collocations like do somebody a favor/harm, which are quite restricted in usage nowadays. Given the great number of enabling verbs found in earlier periods, we postulate a more productive schema for this category in Proto-Germanic, covering a wider range of semantic subclasses.

One major anomaly in research on the ditransitive construction in Modern English is the existence of verbs like forgive, which express a mental process (Goldberg 1995: 132, Colleman \& De Clerck 2011: 198-200), not associated with the transfer schema. Our Gothic and Old English examples show that the concept of forgiving was structured differently in early Germanic than in the Modern Germanic languages. Forgiving was conceptualized as an intensified version of granting and allowing, as shown in $(5 a-b)$ below:

(5a) Old English

ic forgyfe de \& ठinum ofspringce pæt land pinre ælðeodignysse

I confer you.DAT and your offspring.DAT the land.ACC your exile.GEN

'And I will give unto thee, and to thy seed after thee, the land wherein thou art a

(5b) Gothic stranger.'

(Genesis 17:8)

Jah blindaim managaim fragaf siun.

and blind.DAT many.DAT gave sight.ACC

'And unto many that were blind he gave sight.' (Luke 7:21)

We believe that what is conceived of as the mental process of forgiving in modern society was conceptualized as a form of granting during medieval times. This goes hand in hand with a change in the reference of the agent; the agent of granting is typically a lord giving out land (5a) or Jesus restoring a precious thing like sight (5b), while the agent of forgiving is a primarily a holy man or a priest. Compare $(5 a-b)$ above with $(6 a-c)$ below:

(6a) Old English

pa gemiltsode se hlaford him \& forgeaf him pone gylt.

then felt sorry the lord.NOM him.DAT and forgave him.DAT the debt.ACC

'Then the lord of that servant was moved with compassion and forgave him the debt.'

(Matthew 18:27) 
(6b) Gothic

fragibip mis pata skapis.

forgive me.DAT this.ACC wrong.ACC.

'Forgive me this wrong.' (Corinthians II 12:13)

Syle us todæg urne dæghwamlican hlaf \& forgyf us ure gyltas

Give us today our daily bread \& forgive us.DAT our.ACC sins.ACC

'Give us day by day our daily bread and forgive us our sins.' (Luke 11:03)

Observe that (6a) can be taken as an intermediate point in a scale from granting and allowing to the modern concept of forgiving, since the direct object is a debt that is written off. The subject in (6a), the lord, is, in other words, granting his servant the forgiveness of debt. The examples in (6b) and (6c), however, clearly show an unmitigated meaning of the modern 'forgive'.

\section{Domain 3: Deictically Specified Transfer}

The main verbal meanings belonging to this conceptual domain are summarized in (7) below, with examples illustrating the ditransitive use for Gothic, Old English and Old NorseIcelandic, respectively:

(7) 'send, lead, bring, carry, drag, pull, wend, turn'

(7a) Gothic

... atbairip mis skatt, ei gasaihvau.

bring me.DAT coin.ACC, that I.see

'... bring me a coin, that I may see.' (Mark 12:15)

(7b) Old English

Soðes ealle pas brohton gode lac of hyra mycelan welan.

truly all those.NOM brought God.DAT offerings.ACC from their great wealth.

'Truly, all these people brought offerings to God off their wealth.' (Luke 21:4)

(7c) Old Norse-Icelandic

pví at ek skal senda pér sending (Njála 131).

for at I.NOM shall send you.DAT shipment.ACC

'Because I will send you a shipment.' (Njála, Ch. 131)

For this conceptual domain, the majority of the verbs involved express the two deictically specified bring-take directions for the transfer. Contrary to the situation in Modern English (Pinker 1987: 110-111), ditransitives specifying continuous causation in some manner are easily found in the early Germanic languages:

(8a) Gothic

atiddja aftra ut Peilatus jah qap im: sai, attiuha izwis ina

went again out Pilatus and said them: see, drag you.DAT him.ACC

'Pilate went forth again, and saith unto them: Behold, I drag him forth to you ...'

(8b) Old English

Hio Beowulfe medoful ætbær

she.NOM Beowulf.DAT mead-cup.full.ACC bore.

'She brought Beowulf a cup full of mead.' (Beowulf 624)

(8c) Old Norse-Icelandic

Bárðr gekk pá að fast að bera peim drykk

Bárðr.NOM went then to fast to carry them.DAT drink.ACC

'Bárður then insisted that they would be served a drink.' (Egils saga, Ch. 44)

In (8a) the animate referent of the direct object is dragged out in front of the beneficiary, with the verb 'drag' expressing the manner of the continuous motion. In (8b) the cup that is offered to the beneficiary is carried with effort due to its heavy weight, also expressing 
manner of motion. In (8c), finally, the verb 'carry' is used in the meaning 'serve', again expressing manner. These examples clearly demonstrate the existence of ditransitives expressing manner in the conceptual domain of deictically specified transfer in the early Germanic languages, as opposed to in Modern English.

\section{Domain 4: Intention}

The main verbal meanings belonging to this conceptual domain are summarized in (9) below, with examples illustrating the ditransitive use for Gothic, Old English and Old NorseIcelandic, respectively:

(9) 'leave, offer, provide, intend, reward, promise, swear, vow, owe'.

(9a) Gothic

nih frauja Sabaop bilipi unsis fraiwa ...

unless lord.NOM Sabaoth.GEN leave us.DAT seed.ACC

(9b) Old English

'except the Lord of Sabaoth had left us a seed ...' (Romans 9:29)

God foresceawað, min sunu, him sylf da offrunge.

God.NOM provide my son him self.DAT the offering.ACC

'My son, God will provide himself the offering.' (Genesis 22:8)

(9c) Old Norse-Icelandic

Pú býðr peim marga kosti góða en ...

you.NOM offer them.DAT many.ACC options.ACC good.ACC but

'You offer them many good options but ...' (Grettis saga, Ch. 78)

This conceptual domain contains verbs specifying intention. Actual transfer, however, is implied in some cases, but is not necessarily mandatory. We emphasize that offers need not involve a willing agent or recipient, nor do they always have to result in transfer of possession:

(10a) Gothic

pamma stautandin puk bi kinnu, galewei imma jah anpara

the.one.DAT hitting you.DAT on cheek.DAT offer him.DAT also other.ACC

(10b) Old Norse-Icelandic

'The one that hits you on the one cheek, offer him also the other.' (Luke 6: 29)

Hann ætlaði prælum sínum dagsverk.

he.NOM intended slaves.DAT his.DAT day.work.ACC

'He intended a full day's work for his slaves.' (Óláfs saga helga, Ch. 23)

The Christian message of offering the other cheek, in the Gothic example in (10a) above, clearly does not necessarily involve a willing agent as most people do not willingly accept a beating. Also, the chieftain in the Old Icelandic example in (10b) has intentions for his slaves that they will carry out a full day's work, irrespective of their disposition.

\section{Domain 5: Creation, Miscreation}

The main verbal meanings belonging to this conceptual domain are summarized in (11) below. We provide three examples of a ditransitive usage for verbs of creation (11a-c), three of preparation/modifying $(12 a-c)$, three examples of creating a path $(13 a-c)$, respectively. We then offer three examples of miscreation in $(14 a-c)$ :

(11) 'do, do good, make, work, build, carpenter, sew, beget, prepare, make ready, roll away, remove, do ill, do harm, hurt, cut, kill, contrive, plot, block a passage'. 
(11a) Gothic

Jah gawaurkjam hlijans prins, pus ainana jah Mose ainana.

and build tents.ACC three, you.DAT one.ACC and Moses.DAT one.ACC

'And let us make three tabernacles; one for thee, and one for Moses.' (Mark 9:5)

(11b) ... hi ... sywodon him ficleaf.

they sewed them.DAT fig.leaves.ACC

'.. they ... sewed fig leaves for themselves.' (Genesis 3:7)

(11c) Old Icelandic

veittú mér pat, at pú sker mér skyrtu, Auðr ...

grant.you me that that you.NOM cut me.DAT shirt.ACC, Auður,

'Do me that favor, Auðr, to sew a shirt (for my husband Thorkel) for me ...'

(Gísla Saga Súrssonar, Ch. 15)

(12a) Gothic

... jah pan jabai gagga, manwja izwis stad ...

and then if l.go prepare you.DAT place.ACC

'... and if I go and prepare a place for you...' (John 14:3)

(12b) Old English

Hig wrohton him pær beorscipe.

they.NOM prepared him.DAT there feast.ACC

'There they made him a supper.' (John 12:2)

(12c) Old Norse-Icelandic

... gera e-m reiðskjót

make somebody.DAT riding.horse.ACC

'... prepare a horse for somebody.' (DN. VI, 248(45)

Verbs of creation in our dataset typically involve building, constructing, sewing, casting figures or writing tablets. What is distinctive for verbs of modifying/preparing is that the theme is modified and made ready for the benefit of the second participant: arranging a room (12a), preparing a feast (12b) or equipping a horse for the rider taking a journey (12c). The "products" processed may have been modified to be rendered edible, like in a feast, or altered to create something new (cf. Barðdal, Kristoffersen \& Sveen 2011: 65).

Turning to verbs denoting transfer along a path in the ditransitive construction, we have been able to verify the presence of such examples in Gothic, Old English and Old Norse-Icelandic:

(13a) Gothic

hvas afwalwjai unsis pana stain af daurom pis hlaiwis?

who.NOM rolls us.DAT the stone.ACC from door this sepulchre?

'Who will roll away the stone from the entrance of the sepulchre for us?' (Mark 16:3)

(13b) Old English

Pu gelæddest Moysen [...] and him weg gerymdest on pære readan sæ.

you.NOM led Moses and them.DAT way.ACC made.room into the red sea.

'You led Moses (and his people) [...] and made room for them across the Red Sea.'

(13c) Old Norse-Icelandic

(ÆLS, Forty Soldiers, B1.3.12)

pá er Varbelgir kómu á Láku, tráđu peir sér gadd í brekkunni. then when Varbelgir arrived at Láka trod they themselves hard.snow in slope.the "when Vorbelgir arrived at Láka, they trod some hard snow for themselves in the slope.' (Fm. IX, 490)

In the Gothic example above, a stone must be rolled away from the entrance of Christ's sepulchre, creating a path of access to the tomb. In the Old English example, Yahweh clears the way for Moses and his people through the Red Sea. We believe that this ditransitive may be an early example of the source construction giving rise to the Modern English Way construction (see Goldberg: 1995: 199-210, Israel 1996, Traugott \& Trousdale 2013: 76-91 and Fanego 2017: 44), where the path is incrementally created by the staff of Moses and God's wind through the sea. Observe that this example differs from the Modern Way 
construction in that the beneficiary is an indirect object and non-reflexive (cf. Barðdal Kristoffersen \& Sveen 2011).

Until now, no examples of transfer along a path in the ditransitive have been found in Old Norse-Icelandic (Barðdal, Kristoffersen \& Sveen (2011: 72). However, we have come across the example in (13c) above for Old Norse-Icelandic, where Vorbelgir prepared the ground for battle by treading on the snow in a hill slope. Treading snow at a given place in order to make it compact and walkable does not entail nontranslational motion with the legs and feet at a static location. Rather, it entails walking around at this place until all the snow has been trodden down. Hence, the "path" is not linear from A to B in (13c), but circular around a specific spot in a slope. In other words, there is still a path that is created including locomotion of the agent, even though this path results in an area of walkable snow and not in a linear path.

Finally, one major difference between the ditransitive construction in the early Germanic languages and Modern English is the frequent use of malefactive constructions for verbs of miscreation, shown in (14a-b) for Gothic and Old Norse-Icelandic, and blocking the path in (15) for Old English.

(14a) Gothic

Jah afmaimait imma auso taihswo

and chopped.off him.DAT ear.ACC right.ACC

'and cut off his right ear.' (John 18:10)

(14b) Old Norse-Icelandic

pá er peir vildu ráđa bana Pórólfi ...

then when they.NOM wanted rule death.ACC Pórólfur.DAT

(15) Old English

'Then when they wanted to do away with Pórólfur ...' (Laxdæla Saga, Ch. 16)

Ac him hæfdon Pene pone weg forseten, [..] ofer pone munt.
but him.DAT had Pene.NOM the way.ACC obstructed over the hill
'However, the Pene (Carthaginians) had blocked his way ... over the hill.'

(Or 4 6.92.31)

Verbs expressing cutting and killing as in (14) above appear in the three daughter languages and the miscreation may be partial or complete (Malchukov, Haspelmath \& Comrie 2007: 51). Often, the concepts of cutting and killing are expressed indistinctly by cognate verbs like Gothic ufsneipan and Old English gesnipan. Malefactive examples of this type (15) are infelicitous in the modern Scandinavian languages and Modern English and examples like (15c) of the precursor of the Way constructions with non-incremental and abruptly halted paths are ungrammatical in Modern English.

\section{Domain 6: Possession, Obtaining and Dispossession}

The main verbal meanings belonging to this conceptual domain are summarized in (16) below. We give one example of obtaining from Gothic (16a), and two example of possession from Old English (16b) and Old Norse-Icelandic (16c). The examples in (17) represent verbs of choosing and the ones in (18) verbs of dispossession:

(16) 'have, own, appropriate, hoard, amass, spare, take, receive, lay hold of, get, buy, obtain, gather, find, earn, choose, deprive, take away, remove, withdraw, steal, cut off, put off'.

(16a) Gothic

Manna sums godakunds gaggida landis franiman sis piudangardja.

man sum noble went country take himself.DAT kingdom.ACC

'Some nobleman went into a country to take a kingdom for himself.' (Luke 19:12)

(16b) Old English

... Ah him lifes geweald.

owns him.DAT life.GEN power.ACC

'(God) has himself power over [everyone's] life.' (Andreas 1036) 
(16c) Old Norse-Icelandic

Höskuldr átti sér dóttur er Hallgerðr hét.

Höskuldr owned himself.DAT daughter.ACC who Hallgerðr was.named

'Höskuldr had a daughter, named Hallgerðr' (Njála, Ch. 3)

According to Pinker (1989: 114-115), verbs of choosing cannot occur in the ditransitive construction in American English; examples like *I chose/selected her a dress are ungrammatical. In spite of the absence of ditransitive uses for Gothic kiusan, the cognates rising from PGmc *keusan and ultimately from PIE *geus 'to taste, relish', are certainly well attested in the other two daughter languages, as shown in $(17 \mathrm{a}-\mathrm{c})$ below, including synonymous verbs like velja 'choose' in Old Norse-Icelandic:

(17a) Old English

Đa cwæð Moyses to losue: Ceos ðe geferan.

then quoth Moses to Joshua: choose you.DAT men.ACC

'Then Moses said unto Joshua: Choose out men for yourself.' (Exodus 17:9)

(17b) Old Norse-Icelandic

Ingimundr kaus sér bústad í hvammi einum.

Ingimundur.NOM chose himself.DAT living.place.ACC in grassy.hollow one

'Ingimundur chose himself a place to live in a grassy hollow.' (Vatndæla saga, Ch 37 )

(17c) valði Sigríðr vinum sínum gjafar.

picked.out Sigríður.NOM friends.DAT hers gifts.ACC

'Sigríður chose gifts to her friends.' (Ólafs Saga Tryggvasonar, Ch.124)

Finally, for the last subclass in this conceptual domain, i.e. verbs of of disowning, also termed verbs of dispossession in the literature (Colleman \& De Clerck 2011: 200-201), consider the examples in (18) below:

(18a) Gothic

... afslaupjandans izwis pana fairnjan mannan mip tojam ripping.off you.DAT the old man.ACC with deeds

'... having ripped yourselves of your old selves, behaving deedfully.' (Colossians 3:9)

(18b) Old English

ær he ætbræd me mine frumcennedan.

before he.NOM snatched me.DAT my first.born.ACC

(18c) Old Norse-Icelandic

'Before he snatched away my first born from me.' (Genesis 27:36)

Erlingr Vikunnar son ... ser fullkomlæga afsiuiaðe ... iardar pær allar.

Erlingur Víggunnar son himself.DAT completely relinquished land the all

'Erlingur Víggunnarson ... completely relinquished his rights to all his land.'

(Norwegian Diplomas 1314: 125:35)

These examples show that verbs of spoliation (18b) and removal (18a, 18c) may express plundering and pillaging, eventually combining with sudden and violent movements, foregrounding the brutality of the transfer. (18a-b) Hence, verbs of dispossession clearly occur ditransitively in all three branches of Germanic.

\section{Domain 7: Retaining}

The main verbal meanings belonging to this conceptual domain are summarized in (19) below. We start with verbs of hindrance in (19) and then proceed to verbs of constraining in (20):

(19) 'forbid, deny, refuse, warn, keep off, defend, oppress, subdue, lay hands on, do evil, set, impose, serve, minister, obey, wash, observe, discharge a debt, put up for confession'. 
(19a) Gothic

... unte mag jah ufhnaiwjan sis alla.

since may and subdue himself.DAT all.ACC

... 'whereby he is able to subdue all things under himself.' (Philippians 3:21)

(19b) Old English

... he sette him weorca mægstras...

he set them.DAT task.GEN masters.ACC

(19c) Old Norse-Icelandic

... He [the Pharaoh] put slave bosses in charge of them ...' (Exodus 1:11)

at vísu ætla ek at verja pér ríki mitt.

al beit intend I to guard you.DAT kingdom.ACC mine

'albeit I intend to prevent you from seizing my kingdom.' (Hákonar Saga, Ch. 169)

Some verbs of hindrance involve transfer, while others do not, as with Goldberg's verbs of refusal (1995: 38); either way a malefactive reading usually applies. For instance, the verb 'to guard', which has cognates in all the three daughters (warjan, werian and verja respectively), refers to forbidding, warding off, or guarding something against someone.

Consider now the following examples illustrating verbs of constraining:

(20a) Gothic

... izwis mik silban fastaida ...

you.DAT my self.ACC fastened

'...I have restrained myself from being burdensome to you ...' (Corinthians II 11: 9)

(20b) Old English

... Đæt he him Norp-Wealas gehyrsumode.

that he.NOM him.DAT North Welsh.ACC made.obedient

'... that he might make the North Welsh obedient to him.' (Chr. 853)

(20c) Old Norse-Icelandic

Fékk konungur prest að setja honum skriftir $\quad$ og ...

got king priest to set him.DAT confession.ACC and

'The king got a priest to make him confess and ...'

(Hallfreðar saga vandræðaskálds, Ch. 11)

A large subclass of verbs of constraining relate to slavery and servility in different ways, involving obedience or submissiveness. Others relate to performing duties, discharging or imposing obligations, etc.

\section{Domain 8: Mode of Communication}

The main verbal meanings belonging to this conceptual domain are summarized in (21) below. We start with verbs of telling and showing (21) before proceeding to verbs expressing instrument of communication (22, albeit with some medieval instruments), closing off with examples of benefactive and malefactive uses of verbs of communication (23):

(21) 'say, speak, talk, call, quote, tell, tell the way, foretell, declare, announce, proclaim, praise, preach, show, indicate, reveal, prove, explain, teach, order, ask, answer, thank, accuse, blame, deny, refuse, renounce, forbid, write, carve runes, sing, recite, chant'.

(21a) Gothic

... aufto qipip mis po gajukon

surely tell me.DAT the proverb.ACC

(21b) Old English

'(You) will surely tell me this parable.' (John 18:39)

... geseoð pone man pe me sæde ealle ping pe ic dyde.

see the man who me.DAT said all things.ACC that I did.

'... see the man who told me everything that I have ever done' (John 4:28). 
(21c) Old Norse-Icelandic

Peir bræðr pökkuðu konungi pann sóma, er hann veitti peim. they brothers.NOM thanked king.DAT the honour.ACC, which he granted them 'The brothers showed their gratitude to the king for the honour shown to them'

(Egils Saga, Ch. 21)

Verbs of communication are well known in the literature on ditransitives. Hence, we focus here on a set of differences between the early languages and Modern English, namely the alleged lack of verbs of instrument of communication, on the one hand, and the presence of benefactive and malefactive uses, on the other.

Verbs of instrument of communication are usually taken to involve modern tools used in everyday communication, like faxing, emailing or texting, Clearly, this level of technological advancement did not exist during medieval times. This, however, does not exclude the existence of other tools used for communication in the medieval world (contra Barðdal 2007: 119; Colleman \& De Clerck 2011: 190-191). In our dataset, verbs involving instruments of communication apply primarily to written messages, like epistles, gospels, etc., runic inscriptions, as well as psalms and songs performed in spells. In fact, the tool used may even be a living person, since messengers played a crucial role in the politics and everyday life of the medieval period. Clearly, messengers are by definition instruments of communication.

(22a) Gothic

wipra harduhairtein izwara gamelida izwis po anabusn.

against heart.hardness your signalled.with.letters you.DAT the parable.ACC

'For the hardness of your heart, he wrote you this parable.' (Mark 10:5)

(22b) Old English

ðæt he him sceolde Gaiuses miltse geærendian.

that he.NOM them.DAT should Gaius.GEN mercy.ACC act.as.messenger

'that he [Philo, a messenger] should beg Caligula's mercy for them.' (Orosius 6,3)

(22c) Old Icelandic

hraðmælt tunga ... opt sér ógótt um gelr.

quick.speaking tongue.NOM often itself.DAT evil.ACC around enchants

'the fast-talking tongue ... often sings itself harm.' (Hávamál 28 (29))

In the Gothic example in (22a), the instrument of communication is the writing tool, in the Old English example in (22b) the instrument is the messenger (Philo, a representative of the Jews exiled from Alexandria), while in the Old Norse-Icelandic example in (22c) the instrument is the song.

Benefactive and malefactive uses of the ditransitive construction with verbs of communication are amply documented in the early Germanic languages, and to a much greater degree than in the modern languages.

(23a) Gothic

ik im Gabriel ... jah wailamerjam pus pata.

I.NOM am Gabriel and praise you.DAT these.things.ACC

(23b) Old English

'I am Gabriel ... [sent to] show you these glad tidings.' (Luke 1:19)

$\mathrm{Nu}$ du me stale tihst...

now you.NOM me.DAT theft.ACC charge

'Since you accuse me of theft ...' (Genesis 31:32)

(23c) Old Norse-Icelandic

... at pú gefir dauðum sök.

that you.NOM give dead.DAT charge.ACC

'... that thou lay blame on dead men.' (Njála, Ch. 82)

It is mostly verbs of saying, quoting and speaking that are found showing benefactive and malefactive uses. In addition, verbs like praising, announcing, blaming or criticizing can only express polarity in one direction or the other. 


\section{Domain 9: Mental Processes}

The main verbal meanings belonging to this conceptual domain are summarized in (24) below, with examples illustrating the ditransitive use for Gothic, Old English and Old NorseIcelandic, respectively:

(24) 'calculate, deem, know, think, ponder, remember, intend, wish, wish well/evil, fear, dread, apprehend, love'.

(24a) Gothic

unte swepauh gup was in Xristau, [...] ni rahnjands im missadedins ... since indeed God was in Christ, not reckoning them.DAT misdeeds.ACC ...

'For God was in Christ indeed, [...] who did not take into account their trespasses'

(24b) Old English

(Corinthians II, 5:19)

Ealle ठe me yfel hogedon ...

all.NOM who me.DAT evil.ACC thought

'May all of them who planned evil for me ...' (Psalm 69, 3)

(24c) Old Norse-Icelandic

Pá skal ek nú, segir hón, muna pér kinnhestinn

then shall I now, says she, remember you.DAT slap.in.the.face.ACC

'I shall from now on revengefully remember that slap on the face' (Njála, Ch. 77)

Verbs denoting mental processes and activities make up the bulk of this conceptual domain. In Old English, verbs like hogian 'to think, intend' and core verbs of mental state such as 'know', 'think', 'wish', 'intend' or 'remember' are relatively well attested. Emotional states and activities also find their way into this domain, which is particularly true of cases like (24b) and (24c) above. In spite of remaining at best marginalized in Modern English and Modern Icelandic, idiomatic structures like mean someone good/ill/harm and ætla einhverjum illt are the modern continuations of expressions like in (24b).

This conceptual domain, moreover, shows obvious connections with Mode of Communication but also with Enabling, as can be observed in Old English unnan god/yfel 'to wish someone well/evil', Old Norse-Icelandic únna e-m ást 'to grant one's love to someone' and Modern English forgive, whose parallels (Gothic afletan ${ }^{2}$ and fragiban ${ }^{2}$, Old English forgiefan $^{2}$, and Old Norse-Icelandic fyrirgefa) accommodate to the semantics of the conceptual domain of Mental Processes despite expressing enabling.

\section{Findings}

In this section, we summarize the main differences between the early Germanic languages and Modern English. We demonstrate the wider typological scope of the ditransitive construction in Proto-Germanic by means of a semantic map (Figure 5) based on Old English. We then continue with a summary of the main differences in terms of narrowly defined semantic verb classes and categories, which we formalize into a second semantic map (Figure 6). Finally, and before proceeding to syntactic reconstruction in Section 6, we model the Proto-Germanic ditransitive construction in terms of a lexicality-schematicity hierarchy (Figure 7), following Croft 2003, Barðdal 2008, 2011a, Barðdal, Kristoffersen \& Sveen), laying out the different levels of conceptual analysis resulting from our study.

Figure 5 shows the typology of the Proto-Germanic ditransitive construction, which we exemplify with Old English. A comparison with the map of the Modern English ditransitive construction in Figure 2, Section 2 above, shows how enlarged the semantic space (demarcated by dashed lines) was in the early Germanic languages, compared to Modern English. The figure also shows that, apart from recipients, beneficiaries and maleficiaries also play a considerably more important role in early Germanic than in Modern English. The scope of the ditransitive construction in Figure 5 is comprehensive, it covers most of the options existing for the modern world's languages, leaving out Internal Possessors and the 
domain involving the use of datives for denoting an instrument with verbs like 'hit, affecting an object. Our findings verify a similar areal distribution in Gothic and Old Norse-Icelandic that we omit here for lack of space.

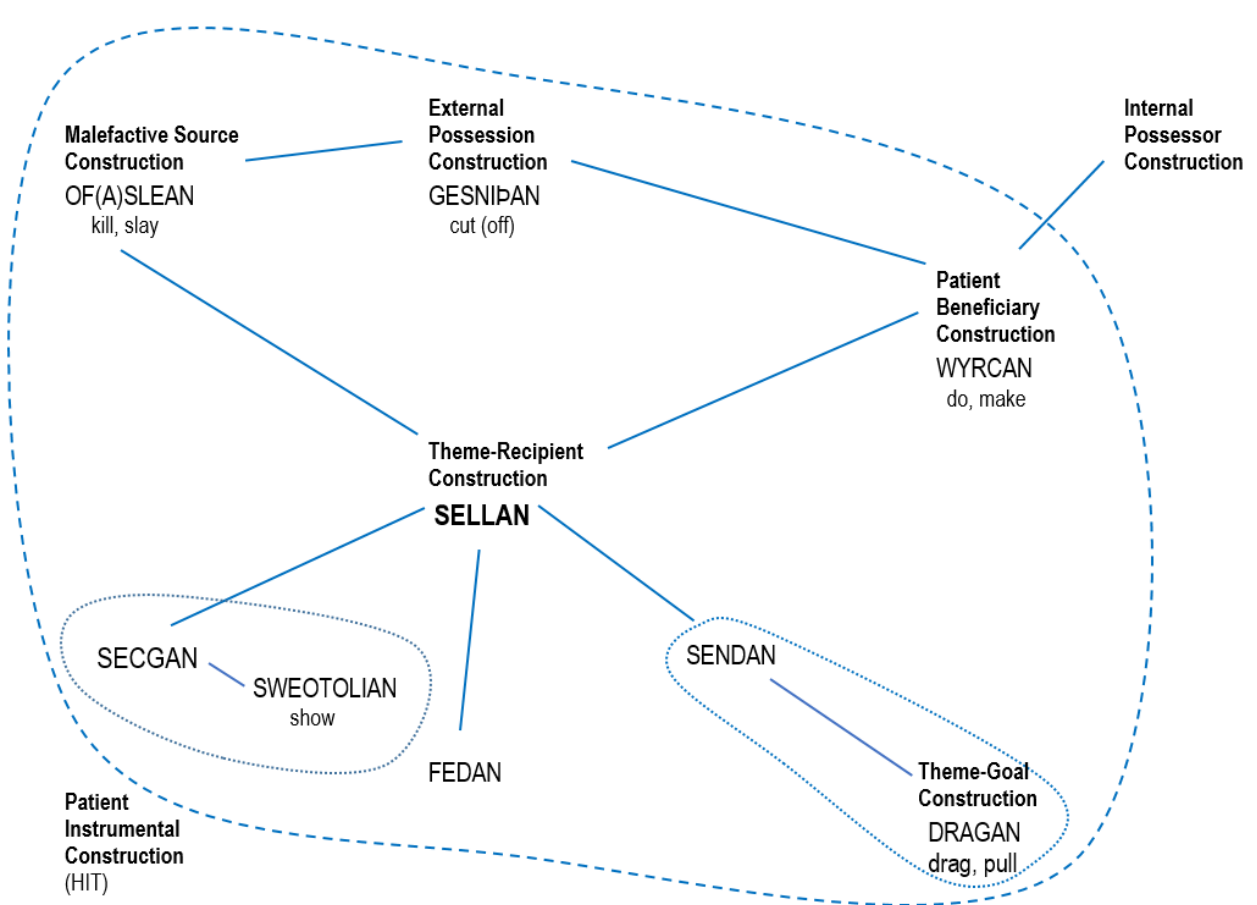

Figure 5: The typology of the ditransitive construction in Old English.

In terms of narrowly defined semantic verb classes, the main differences found in Section 4, instantiating the ditransitive construction across early Germanic and Modern English, are summarized below:

- Verbs of distributing, a subclass of verbs of giving (2), are well attested in the earliest documented stages of all three branches of Germanic, as opposed to in the modern Germanic languages.

- Verbs of enabling (9) are considerably more numerous and productive in the early Germanic languages than in Modern English, where only allow and permit are found (Goldberg 1995: 38). One current verb of mental process, 'forgive', did not mean 'forgive' in Old English, but 'grant' or 'cancel a debt'. The occurrence of this mental process verb in the ditransitive construction in Modern English is presumably an inheritance from an earlier period where the verb meant 'grant' and was a verb of enabling.

- Deictically specified verbs of continuous motion expressing manner, like 'drag' and 'carry' (5), are found in all the Early Germanic languages, as opposed to in Modern English (consider the ungrammaticality of *I carried/pushed John the box, Pinker 1989: 111).

- Verbs of transfer along a path (8) are attested in the early Germanic languages, present also in the Modern Germanic languages, but absent from Modern English

- Verbs of owning (1) are attested in Old English and Old Norse Icelandic, exactly as in Modern Icelandic, but are very restricted in Modern English and Modern Norwegian, having even developed a special lexicalized subsense of 'treating oneself to something good' in that language (cf. Barðdal, Kristoffersen \& Sveen 2011: 8296).

- Verbs of choosing, a subclass of verbs of obtaining (13), may instantiate the ditransitive construction in both Old English and Old Norse-Icelandic, while it is 
ungrammatical in Modern English (Pinker 1989: 99), as opposed to the other modern Germanic languages.

- Verbs of (dis)possession are attested in all three early branches of Germanic, as opposed to in the modern Germanic languages including Modern English. This is true for verbs of removal and spoliation (13).

- As opposed to earlier claims in the literature, verbs of instrument of communication (11) do occur in the ditransitive construction in all three early branches of Germanic, with the instrument being, for instance, a feather pen, a human messenger or a song in, for instance, hymns or spells.

In addition to these changes in individual narrowly defined semantic verb classes, we have further documented three major differences between the early Germanic languages and Modern English. These are:

- General benefactive and malefactive uses with verbs of communication (10) in the early Germanic languages.

- General benefactive and malefactive uses with verbs of mental processes (17) in the early Germanic languages.

- General malefactive uses with verbs of miscreation (12) in the early Germanic languages.

Hence, benefactives and malefactives are amply documented in the early Germanic languages, while they do not instantiate the ditransitive construction in the modern Germanic languages to the same degree. In this respect, the model presented by Barðdal (2007) and Barðdal, Kristoffersen \& Sveen (2011), based on North Germanic, and in particular on Old Norse-Icelandic, discussed in Section 2 above, paints a different picture for benefactives and malefactives than the one emerging here, based on a wider selection of early Germanic language, i.e. Gothic and Old English. Therefore, we have documented a considerably wider use of ditransitives with benefactive and malefactive meaning, a characteristics of the ditransitive construction itself which we believe may be reconstructable for Proto-IndoEuropean, as Gothic and Old English are chronological considerably older languages than Old Norse-Icelandic.

While not doing full justice to the complex links between the different conceptual domains of the ditransitive construction, Figure 6 presents our attempt at visually reconstructing the semantic structure of the ditransitive construction in Proto-Germanic on the basis of the presentation in Sections 3.2 and 4 above and in consonance with the typology presented in Figure 5. Thus, we have followed the structure of the semantic map in Figure 5 and positioned in conceptual space the 16 relevant verb-specific classes presented in Section 2 above (Barðdal 2007; one of original verb classes, denoting verbs of using, was in general not found in Gothic or Old English, hence the reduction of verb classes to 16 here). The advantage of the semantic map in Figure 6 is that the partial continuity of the verb classes is easily modeled and their location in their respective conceptual domains is accounted for.

Our findings from Gothic, Old English and Old Norse-Icelandic corroborate the existence of intended and metaphorical transfer, as in the modern languages, but we also document benefactive and malefactive transfer, to a much greater degree, and even lack of transfer, for that matter. Actual transfer occupies a central position in Figure 6, found with verbs of giving (2), distributing (2), paying (2), entrusting (2), with verbs of conferring (9), lending (9), sending (5) and bringing (6), exactly like in the modern Germanic languages and English. Further verbs of enabling and giving include allowing (9), forgiving (9) and offering (9), located closer to the benefactive space.

Verbs of (dis)possession, like owning (1), spoiling (13), removing (13) and obtaining (13) are located closer to the malefactive and the benefactive domains, as they may represent each of the two opposite poles. Verbs of creating (12), modifying (12) and transfer along a path (8) are located close to the benefactive domain, and the opposite is true for verbs of miscreation, which are killing and cutting on the map (12), blocking a path (8), hindrance (15), and constraining (16). Also, some events denoted by verbs belonging to 
Mode of Communication, Mental Processes and Intention may sometimes fall onto the benefactive and malefactive clines.

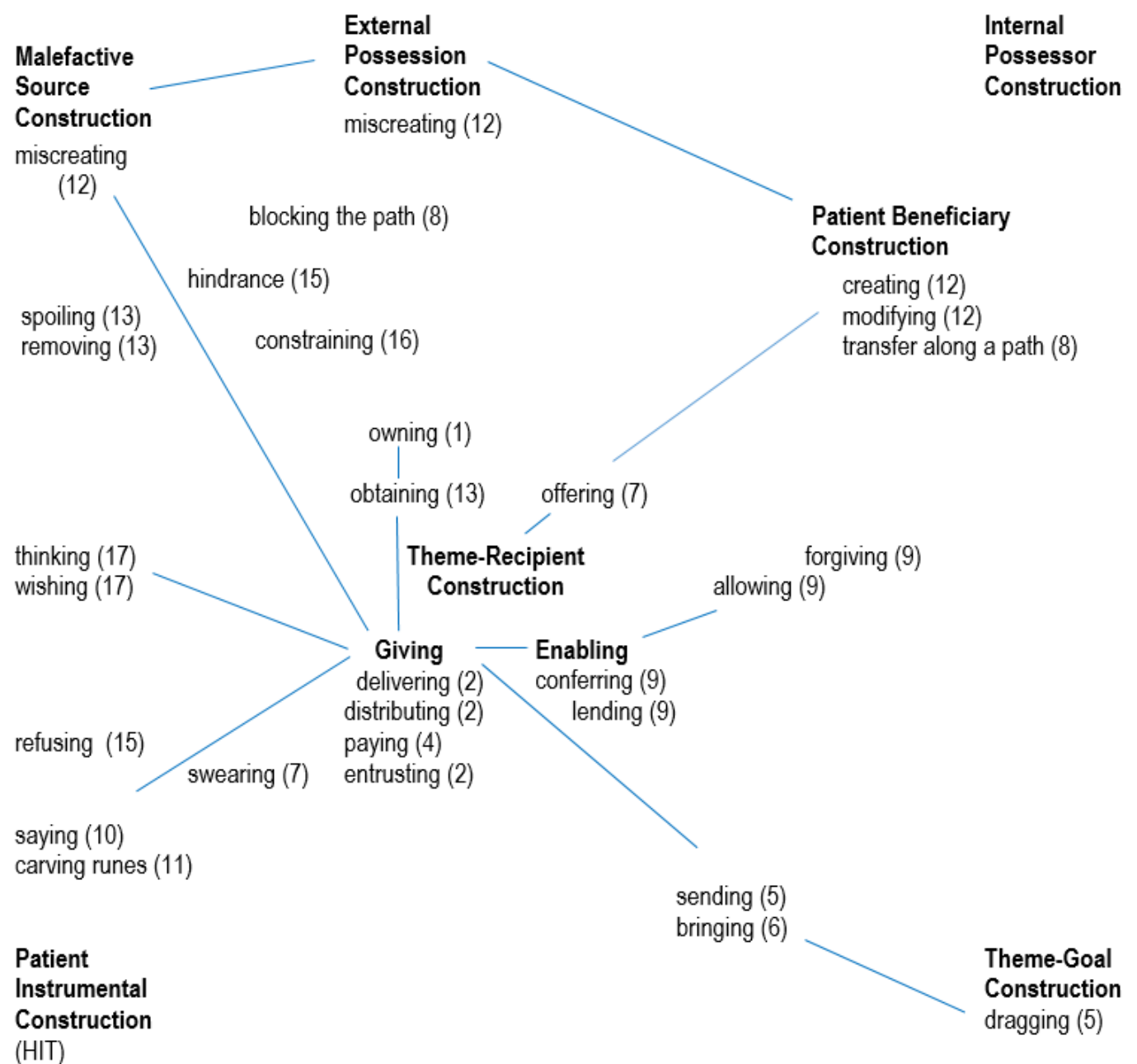

Figure 6: The semantics of the ditransitive construction in Proto-Germanic.

The differences in the number and types of constraints found for the ditransitive construction between early Germanic and Modern English are significant but not necessarily at odds with each other: the volitionality of the agent is still predominant in Modern English but does not always apply, for instance with verbs of letting and allowing (9). Willingness on the part of the recipient is also common but also more frequently irrelevant in early Germanic and nonapplicable to affected referents in the malefactive space. There are clear power relation constraints superimposing agent over recipient in the conceptual domain of enabling (2) in early Germanic. Moreover, the role of satisfaction conditions in the early Germanic languages goes beyond promising (10) in Intention or guaranteeing (7) in Mode of communication, covering verbs of entrusting (2), returning (2) and, also, a significant number of retaining verbs (16).

On the whole, the evidence found points to a typologically enlarged portrayal of the ditransitive construction in the early Germanic languages when compared with the modern languages, not only Modern English but also Modern Icelandic, with the most significant differences found for the verb classes belonging to the malefactive and benefactive domains. Although unexpected from an Anglocentric perspective, this picture conforms to existing knowledge of the ditransitive construction in the Standard Average European languages (Haspelmath 1999: 109-136). 
However, Malchukov, Haspelmath \& Comrie (2007: 40-52) acknowledge that there may be gaps in their model. They claim, for instance, that modern Standard Average European Languages like Modern German and Modern Russian show an open list of verb classes instantiating the ditransitive construction, in other words, that the verb slot in the ditransitive construction is schematically open, as opposed to the situation in most of the world's languages. As such, the ditransitive construction in the Standard Average European Languages is an anomaly, they claim, compared to the ditransitive construction crosslinguistically. Our study, however, carried out on three early Germanic, i.e. European, languages, does not corroborate their claims. We demonstrate that the list of verb classes associated with the ditransitive construction in early Germanic, however long and complex these may be, is indeed closed.

To further contribute to a typological discussion, we have rendered our findings from the early Germanic languages in terms of Malchukov, Haspelmath \& Comrie's original semantic map of the ditransitive construction, given in Figure 2 in Section 2 above. There is, however, one major disadvantage with a map of this type, namely that it abstracts away from low-level verb classes, which in turn make up the foundation of the semantic analysis conveyed by the map. While there are certainly benefits of such higher-level generalizations, we still believe that lower-level verb classes should be represented in such maps. We have shown, in Figure 6, exactly how this may be done.

In contrast, one major advantage of using lexicality-schematicity hierarchies when representing argument structure is indeed the reconciling of the specifics of individual lexical items with the more schematic in conceptual space (Croft 2003). Through such a representation may the particularities of verb-specific items, encoded at the lowest and most specific level of categorization, gradually contribute to higher-level generalizations at an increased level of abstractness. We thus propose the lexicality-schematicity hierarchy for the ditransitive construction in Proto-Germanic as represented in Figure 7.

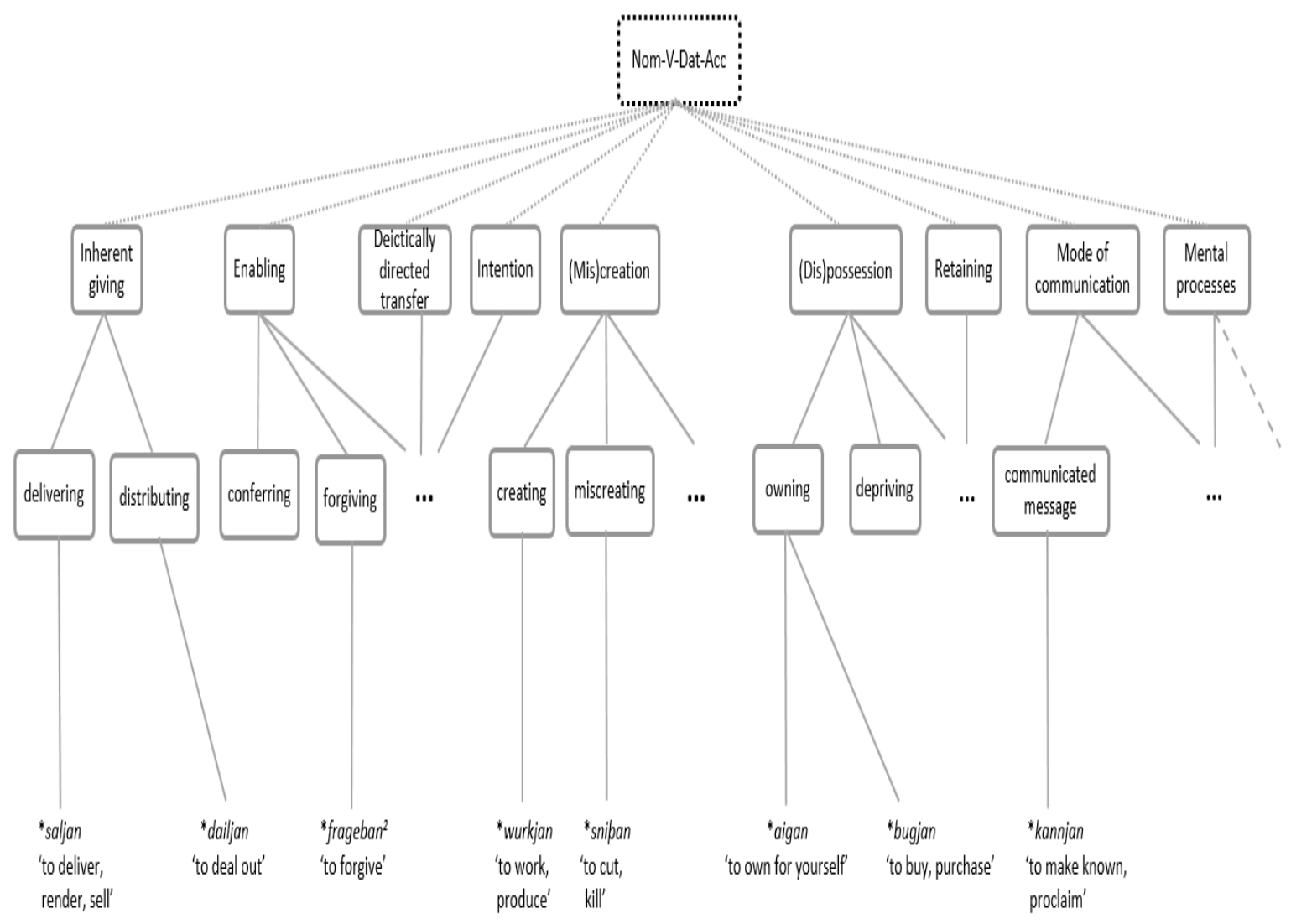

Figure 7: The Lexicality-Schematicity hierarchy of the ditransitive construction in ProtoGermanic. 
The highest level in the hierarchy instantiates the most schematic level of the construction, the very combination of form - the V-Dat-Acc - consisting only of relational meaning, due to its high level of schematicity. The level immediately below is occupied by the nine higherlevel conceptual domains found for ditransitives, presented in Section 3.2., i.e. Giving, Enabling, Deictically Directed Transfer, Intention, (Mis)creation, (Dis)possession, Retaining, Mode of Communication and Mental Activity. The level below that encompasses the 25 narrowly circumscribed verb-class-specific constructions, found in Figure 6 above: delivering, distributing, entrusting and paying (2), conferring, lending, allowing and forgiving (9) sending, bringing and dragging $(5,6)$, offering and swearing (7), creating, modifying (12), transfer along a path (8), miscreating (12), blocking the path (8), owning, obtaining, hindrance (15), constraining (16), saying (10), carving runes (11) and thinking and wishing (17).

The lowest level in Figure 7 represents verb-specific constructions, i.e. the individual lexical verbs with their verb-specific argument structure constructions. It is at this level where the diverse lexical range of ditransitive verbs in our dataset materializes (see Section 3.1 above), containing verbs like *dailjan 'to deal out' and reflexives such as *aigan 'to own for yourself', for instance. For lack of space, we have not included the bottom level of the hierarchy in Figure 7, which corresponds to verb-subspecific constructions distinguishing prefixed and unprefixed counterparts when these show the same meaning.

We now proceed to the syntactic reconstruction in Section 6.

\section{The Syntactic Reconstruction}

Before delving into the syntactic reconstruction of the ditransitive for Proto-Germanic, a few words on the feasibility of syntactic reconstruction are in order. It has been assumed for a long time that syntactic reconstruction is excluded in historical-comparative linguistics for several different reasons (cf. Watkins 1976, Jeffers 1976), Lightfoot 1979, Winter 1984). For lengthy discussions of these reasons, and arguments against them, we refer the reader to Gildea (1992, 1998, 2000), Harris \& Campbell (1995), Kikusawa (2002, 2003), Harris (2008), Willis (2011), Eythórsson \& Barðdal (2011, 2016), Barðdal \& Eythórsson (2012a, 2012b, 2019), and Barðdal (2013, 2014), inter alia.

One very important argument against syntactic reconstruction, which we would like to focus on more closely here, is based on the assumption that syntax is not assumed to consist of form-meaning pairings, which is by definition the unit of comparanda assessed by the Comparative Method. Instead, sentence meaning is assumed to be a derivative of the combined meaning of the lexical items instantiating that sentence. This assumption has its roots in the traditional/structuralist paradigm (cf. Klein 2010), and was from there taken over by the generative paradigm. It is clear that on this assumption, there can be no reconstruction of syntax, since no inherent meaning is assumed to accompany syntactic objects. However, with the emergence of Construction Grammar (Lakoff 1987, Fillmore, Kay \& O’Connor 1988, Goldberg 1995, Jackendoff 1997, Kay \& Fillmore 1999, Michaelis \& Ruppenhofer 2001, Croft 2001, Fried \& Östman 2005, inter alia), this view becomes invalid, since on a constructional account syntactic objects are indeed regarded as form-meaning pairings in their own right. From there, the leap is minimal to historical form-meaning pairings, functioning as input to the Comparative Method. In other words, on a Construction Grammar view of grammar and syntax, syntactic objects are also form-meaning correspondences exactly like words, hence they are also reconstructable. In the remainder of this article, we demonstrate how such an enterprise may be carried out, using the wellknown box formalism of Construction Grammar (cf. also Barðdal \& Eythórsson 2012b, Barðdal et al. 2013, Barðdal \& Smitherman 2013, Danesi, Johnson \& Barðdal 2017, 2018).

As evident from the overview presented in Section 5. above, there are several cognate verbs found across the three different Germanic branches instantiating the ditransitive construction. We have found 24 cognates across all three branches, ten cognates across Gothic and Old English, three across Gothic and Old Norse-Icelandic, and finally 30 across Old English and Old Norse-Icelandic. These cognate sets are listed below, 
further providing us with material for the correspondence sets needed to carry out the relevant syntactic reconstructions:

\section{Gothic, Old English, Old Norse-Icelandic Old English, Old Norse-Icelandic}

giban (Goth), (a)giefan (OE), gefa (ON-I) 'grant, give'

fragiban $^{2}$ (Goth), forgiefan ${ }^{2}(\mathrm{OE})$, fyrirgefa

(ON-I) 'forgive'

andsaljan (Goth), sellan (OE), selja (ON-I)

'give, to deliver'

gadailjan (Goth), dælan (OE), deila (ON-I)

'deal out'

anafilhan (Goth), befeolan (OE), fela (ON-I)

'give into the care of, commit to sb for safekeeping'

fraletan (Goth), Iætan (OE), láta (ON-I) 'let, let free'

uslaubjan (Goth), Iyfan (OE), leyfa (ON-I)

'permit, allow, give leave'

usgildan (Goth), gieldan (OE), gjalda (ON-I) 'pay (back)'

gamipsandjan (Goth), sendan (OE), senda

(ON-I) 'send (with)'

swaran (Goth), swerian (OE), sverja (ON-I) 'swear (an oath)'

haban (Goth), habban (OE), hafa (ON-I) 'have'

qiban (Goth), cweđan (OE), kveđa (ON-I) 'say'

kannjan (Goth) gecennan (OE), kenna (ON-

I) 'make known, proclaim, teach'

anabiudan (Goth), bebeodan (OE), bjóđa

$(\mathrm{ON}-\mathrm{I})$ 'command, instruct, bid'

bugjan (Goth), bigcan (OE) 'buy, purchase', byggja (ON-I) 'allot'

atbairan (Goth), beran (ON-I) bera (ON-I) 'carry'

warian (Goth), werian (OE), verja (ON-I) 'guard'

fastan (Goth) ætfæstan (OE), festa (ON-I) 'afflict, assign'

fastan (Goth), ætfæstan (OE), festa (ON-I)

'have in custody, fasten'

gameljan 'write' (Goth), mapelian (OE), mæla 'speak, decide' (ON-I)

gateihan (Goth), teon (OE), tjá (ON-I) 'report, show'

gatimrjan (Goth), (ge)timbrian (OE), timbra (ON-I) 'build, carpenter'

niman (Goth), niman (OE), nema (ON-I) 'take'

uf-sneipan (Goth), gesniban (OE), sniða

$(\mathrm{ON}-\mathrm{I})$ 'cut, kill'

Gothic, Old Norse-Icelandic: ræcan (OE), rétta (ON-I) 'hand over' lænan OE), lána (ON-I) 'lend, grant' leanian (OE), launa (ON-I) 'reward' gegearwian (OE), gera (ON-I) 'prepare, do' tosecan 'to find out and take' (OE), sækja

(ON-I) 'fetch'

tellan (OE), telja (ON-I) 'tell'

bodian (OE), boða (ON-I) 'pronounce,

preach'

gewisian (OE), vísa (ON-I) 'show'

gesettan (OE), setja (ON-I) 'set'

findan (OE), finna (ON-I) 'find'

geceosan (OE), kjósa (ON-I) 'choose'

onfon (OE), fá (ON-I) 'receive, get'

secgan (OE), segja (ON-I) 'say'

Iæfan (OE) leifa (ON-I) 'leave'

beodan, gebeodan (OE) bjóđa (ON-I) 'offer'

agan (OE; refl.), eiga sér e-t (ON-I) 'own'

agnian land (OE), eigna sér land (ON-I)

'appropriate, attribute land'

sparian (OE), spara (ON-I) 'spare, save'

geceapian (OE), kaupa (ON-I) 'to buy, purchase'

unnan (OE), unna (ON-I) 'grant'

deman (OE), dœma (ON-I) 'adjudge'

hogian (OE), huga (ON-I) 'think'

gemunan (OE), muna (ON-I) 'think, remember'

scirian (OE), skera (ON-I) 'cut, allot'

gehalgian (OE), helga (ON-I) 'consecrate, appropriate holily'

fedan (OE), fæða (ON-I) 'feed, raise, give birth to'

leon (OE), ljá (ON-I) 'lend'

betæcan (OE), tjá (ON-I) 'entrust, present'

begietan (OE), geta 'get, beget'

pancian (OE), pakka 'thank'

\section{Gothic, Old English}

gawaurkjan (Goth), wyrcan (OE) 'make, prepare'

gataujan (Goth), don (OE) 'do, make'

huzdjan (Goth), goldhordian (OE) 'hoard'

laisjan (Goth), læran (OE) 'teach'

gasatjan namna (Goth), onsettan nama

(OE) 'surname'

pwahan (Goth), gepwean (OE) 'wash'

afslahan (Goth), ofslean (OE) 'cut off, kill'

uslukan (Goth), onlucan (OE) 'open, reveal'

taiknjan (Goth), getacnian (OE) 'show'

gawadjon (Goth), beweddian (OE) 'pledge' 
rahnjan 'reckon, count' (Goth), reikna (ON-I)

'count, calculate'

gabairhtjan (Goth) 'make appear', birta (ON-

I) 'show'

ustiuhan (Goth), tjá (ON-I) 'express'

It is customary in historical-comparative Indo-European linguistics to reconstruct on the basis of correspondences from at least three different branches. Since there are only three branches in Germanic, East-, West- and North-Germanic, this would require evidence from all three of them. However, we believe that a reconstruction is possible on the basis of only two branches, provided that the quality of the data is good, given the scarcity of the Gothic corpus. We also know that there was no contact between East- and North-Germanic, nor between East- and West-Germanic (cf. Green 1998). There was indeed contact between Old Norse-Icelandic and Old English, but this contact was in the late Old English period while our Old English verbs above are all (but the three specified in fn. 3 above) documented earlier than that. Nevertheless, for the sake of this methodological exercise, we limit the reconstruction below to verb-specific argument structure constructions that are found in all three branches.

Consider, now, the following examples with kannjan, gecennan and kenna from Gothic, Old English and Old Norse-Icelandic, respectively:

(25) kannjan, gecennan, kenna

(25a) Gothic

kannjan izwis allata.

make.known you.DAT everything.ACC

'make everything known to you.' (Ephesians 6:21)

(25b) Old English

Ic be ecne God ænne gecenne.

I.NOM you.DAT eternal.ACC God.ACC one.ACC prove

'I will prove you the only everlasting God.' (Grn. Hy. 10, 4)

(25c) Old Norse-Icelandic

kenna henni allan fróðleik, er peir kunnu at kenna.

teach her.DAT all.ACC knowledge.ACC that they knew to teach

'teach her all the knowledge they possessed themselves.' (Konr. 50(23))

The lexical verb itself has already been reconstructed for Proto-Germanic by the etymologists as *kannjan- on the basis of the evidence from the daughters (cf. Kroonen 2013: 279). Our aim here, however, is to reconstruct an argument structure construction for the Proto-Germanic *kannjan-, also on the basis of the evidence from the daughters, in this case on the basis of the argument structure constructions found in the examples in (25) above.

Table 2: A correspondence set for kannjan, gecennan and kenna

\begin{tabular}{ll}
\hline & Alt 1 \\
\hline Gothic & NOM-kannj--DAT-ACC \\
Old English & NOM-cenn--DAT-ACC \\
Old Norse-Icelandic & NOM-kenn--DAT-ACC \\
\hline
\end{tabular}

As is clear from these examples, the documented verbs kannjan, gecennan and kenna selected for the same case and argument structure constructions in all three branches, namely nominative subject, dative indirect object and an accusative direct object. A correspondence set may thus be set up for the argument structure of these verbs as in Table 2 , which shows this uniformity across the daughters, with only one alternant for all three languages, namely NOM-V-DAT-ACC. The label NOM stands for the first argument of the 
argument structure, the nominative subject, DAT stands for the second argument of the argument structure, the dative indirect object, while ACC stands for the third and last argument of the argument structure, the accusative direct object.

On the basis of the already reconstructed form, *kannj- and the correspondence set in Table 2 containing the relevant argument structure constructions, a reconstruction as in Figure 8 of the verb-specific construction for 'make known' emerges. Following Barðdal \& Eythórsson (2012a, 2012b), Barðdal \& Smitherman (2013) and Barðdal et al. (2013), we suggest a reconstruction using the formalism of Construction Grammar (Kay \& Fillmore 1999, Michaelis \& Ruppenhofer 2001, Fried \& Östman 2005, Sag 2012, Michaelis 2010, 2012). This involves a box notation with different fields, of which only three fields are relevant here, namely the FORM field, the SYN field and the SEM field. The asterisk in the upper left corner indicates that this is indeed a reconstruction.

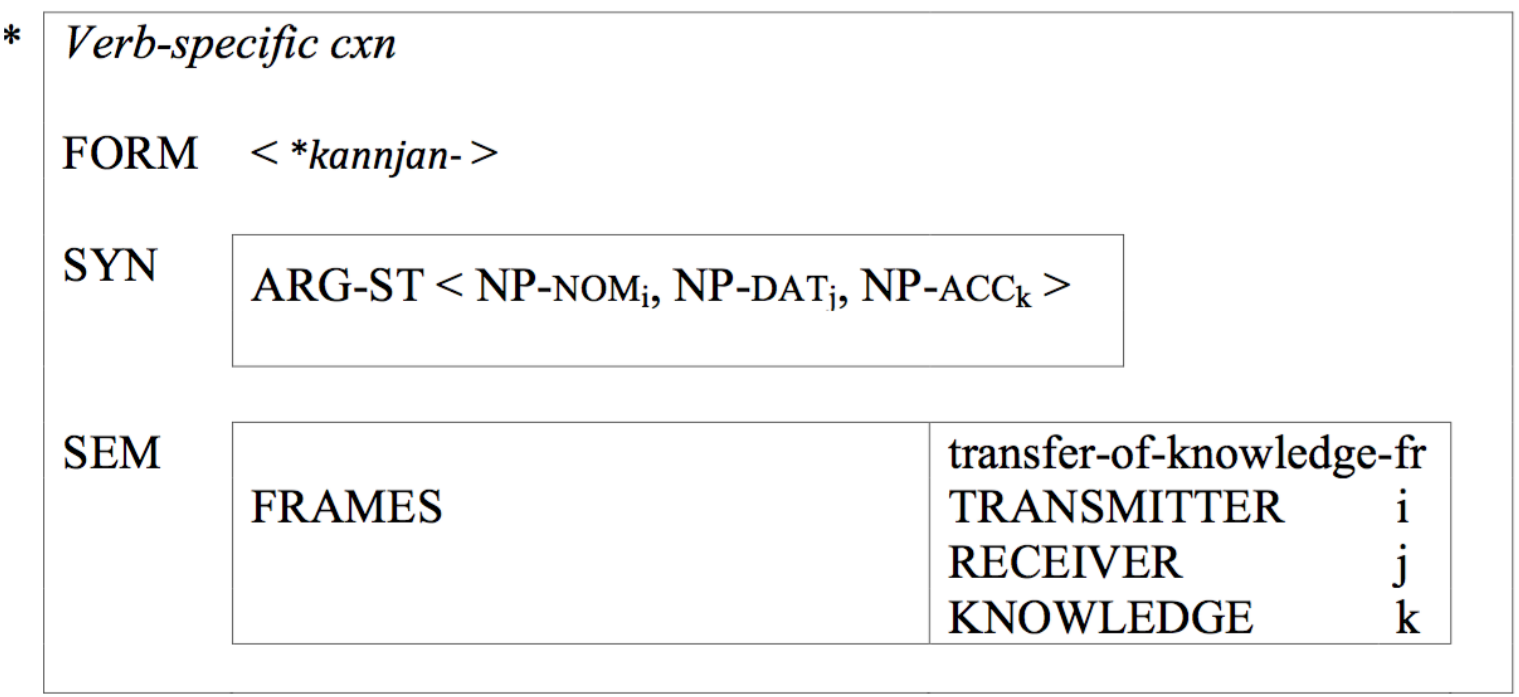

Figure 8: A reconstruction of the verb-specific NOM-kannjan-DAT-ACC construction in Proto-Germanic

The FORM field specifies the form of the verb, in this case the already reconstructed form *kannjan. The SYN field contains the argument structure, i.e the number of arguments, the relevant case marking and the internal order of the arguments. Each of the arguments is indexed with a number corresponding to the indexes found for the frame-specific participant roles given in the third field, namely Transmitter, Receiver and Knowledge. This third field, the SEM field, is here specified in terms of a semantic frame adopted from FrameNet (Baker, Fillmore \& Lowe 1998, Baker, Fillmore \& Cronin 2003), namely the frame of transferring knowledge from a transmitter to a recipient. We believe that we need such a widely defined frame for *kannjan since the meanings in the daughters range from 'make known' to 'prove' to 'teach'. In addition, this frame also matches the oldest attested meaning, 'make known' from Gothic, best.

Let us illustrate this with another example, namely bugjan, bigcan and byggja, which mean 'buy, purchase' in Gothic and Old English but 'allot' in Old Norse-Icelandic.

(26) bugjan, bigcan, byggja

(26a) Gothic

weis ... bugjaima allai bizai manseidai matins.

we buy all.DAT these.DAT people.DAT meat.ACC

'we ... buy meat for all these people.' (Luke 9:13)

(26b) Old English

sylle his tunecan \& bicge him swurd.

sell his garment and buy himself.DAT sword.ACC

'to sell his garment and buy himself a sword.' (Luke 22:36) 
(26c) Old Norse-Icelandic

hann ... bygði pat frændum sínum.

he ... parcelled that.ACC allies.DAT his.DAT

'he ... parcelled it [the land] out to his allies.' (Landnáma 244)

The correspondence set for bugjan, bigcan and byggja is shown in Table 3, again illustrating the same uniformity in case frame across the daughters, i.e a nominative subject, a dative indirect object and an accusative direct object.

Table 3: A correspondence set for bugjan, bigcan and byggja

\begin{tabular}{ll}
\hline & Alt 1 \\
\hline Gothic & NOM-bugj- -DAT-ACC \\
Old English & NOM-bigc--DAT-ACC \\
Old Norse-Icelandic & NOM-byggj--DAT-ACC \\
\hline
\end{tabular}

\begin{tabular}{|c|c|c|c|}
\hline \multicolumn{4}{|c|}{ Verb-specific cxn } \\
\hline FORM & \multicolumn{3}{|l|}{$<{ }^{*}$ bugjan $->$} \\
\hline SYN & \multicolumn{2}{|c|}{ ARG-ST $<$ NP-NOM, NP-DAT $i, ~ N P-A_{i C C}>$} & \\
\hline SEM & FRAMES & $\begin{array}{l}\text { transfe } \\
\text { BUYE } \\
\text { RECEI } \\
\text { GOOD }\end{array}$ & $\begin{array}{l}\mathrm{i} \\
\mathrm{j} \\
\mathrm{k}\end{array}$ \\
\hline
\end{tabular}

Figure 9: A reconstruction of the verb-specific NOM-bugjan-DAT-ACC construction in ProtoGermanic

On the basis of the reconstructed form, ${ }^{*}$ bugj- (Kroonen 2013: 82) and on the basis of the correspondence set in Table 3, a reconstruction may be suggested as in Figure 9 of the verb-specific construction for 'buy' in Proto-Germanic. As with 'make known' above, the FORM field specifies the already reconstructed form *bugjan. The SYN field contains the three arguments in the argument structure and the relevant case frame. In this particular case, the frame-specific participant roles given in the SEM field are Buyer, Receiver and Goods, derived from the semantic frame of transferring goods from a buyer to a receiver. We take it that the Gothic and the Old English meanings reflect the original state of affairs in Proto-Germanic.

In addition to these two verb-specific reconstructions for Proto-Germanic, we propound a reconstruction of higher-level categories such as verb-subclass specific reconstructions and verb-class-specific reconstructions, as well as a reconstruction of a highest-level event-type construction for Proto-Germanic on the basis of the data presented in the Appendix and in Section 4 above. Thus, continuing with, for instance, 'make known', reconstructed in Figure 8 above, this verb makes up a small subclass with two other ditransitive verbs denoting communicated message. These are the verbs 'say' (Goth qipan, OE cweđan, ON-I kveđa) and 'command' (Goth anabiudan, OE bebeodan, ON-I bjóða), both of which are found across the three branches in cognate form. However, in order to reconstruct a verb-subclass-specific construction, the formalism needs to be adapted. 
We propose that the SEM field in our box representation be modified to accommodate verb subclasses and verb classes, since these are semantic abstractions over individual verbs and that, instead of participant frames, the verb classes be specified, including the relevant reconstructed lexical items. This is shown in Figure 8 for the verbsubclass-specific construction of Communicated Message, including the cognate verbs which make up this class, namely the reconstructed *kwepan-, *kannjan and *beudan. At this point, we do not postulate that these three verbs were the only verbs that instantiated this verbal subclass in Proto-Germanic, hence the ellipsis. Rather, our reconstruction is only based on the lexical evidence for which we have found cognate material across the three daughter branches.

The FORM field in Figure 10 is empty, as this is not a reconstruction of a named verb-specific construction with a specific phonological form, as in Figures 8-9 above, where the verbs *kannjan- and *bugjan- are reconstructed. Instead, this is a verb-subclass-specific reconstruction, which is schematic by definition and can thus not have any phonological form. The same also applies to verb-class-specific and event-type constructions.

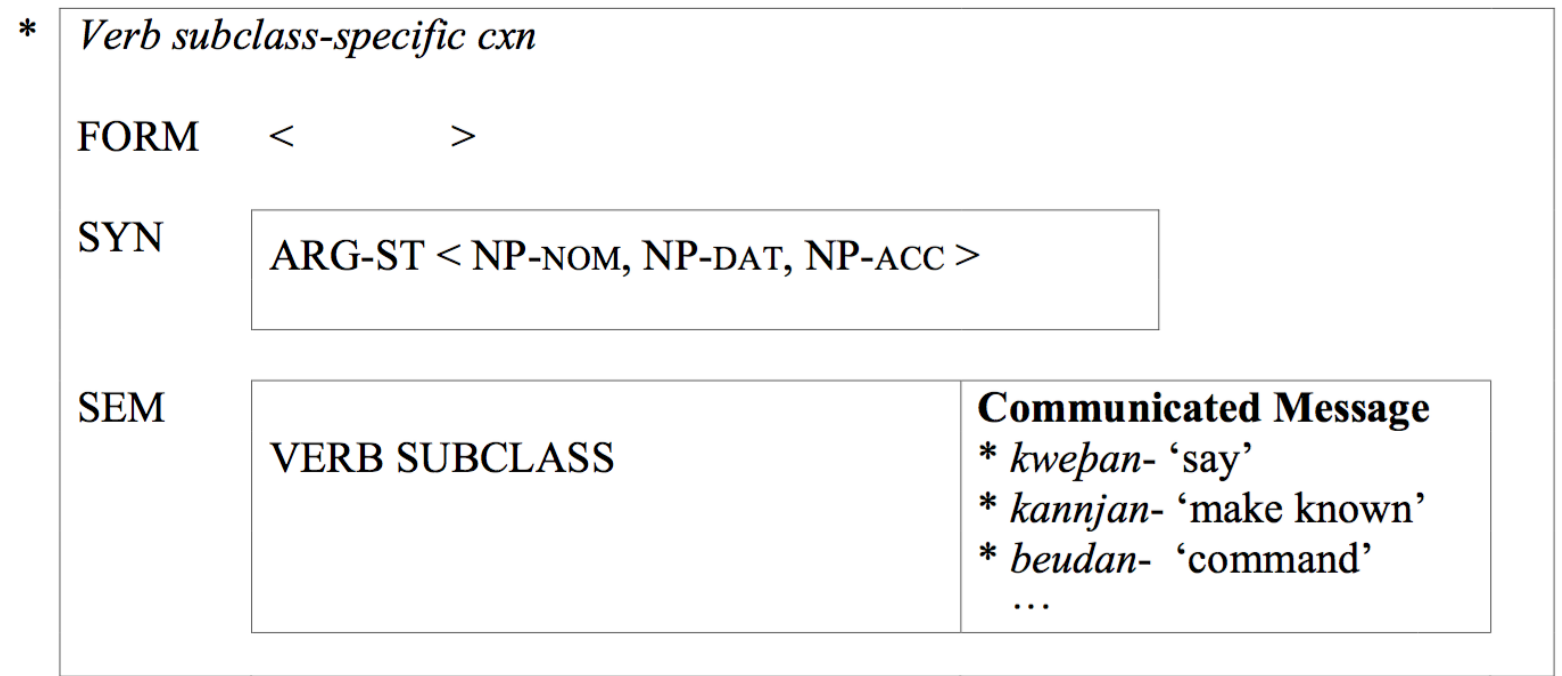

Figure 10: A reconstruction of the verb-subclass-specific construction "Communicated Message" in Proto-Germanic

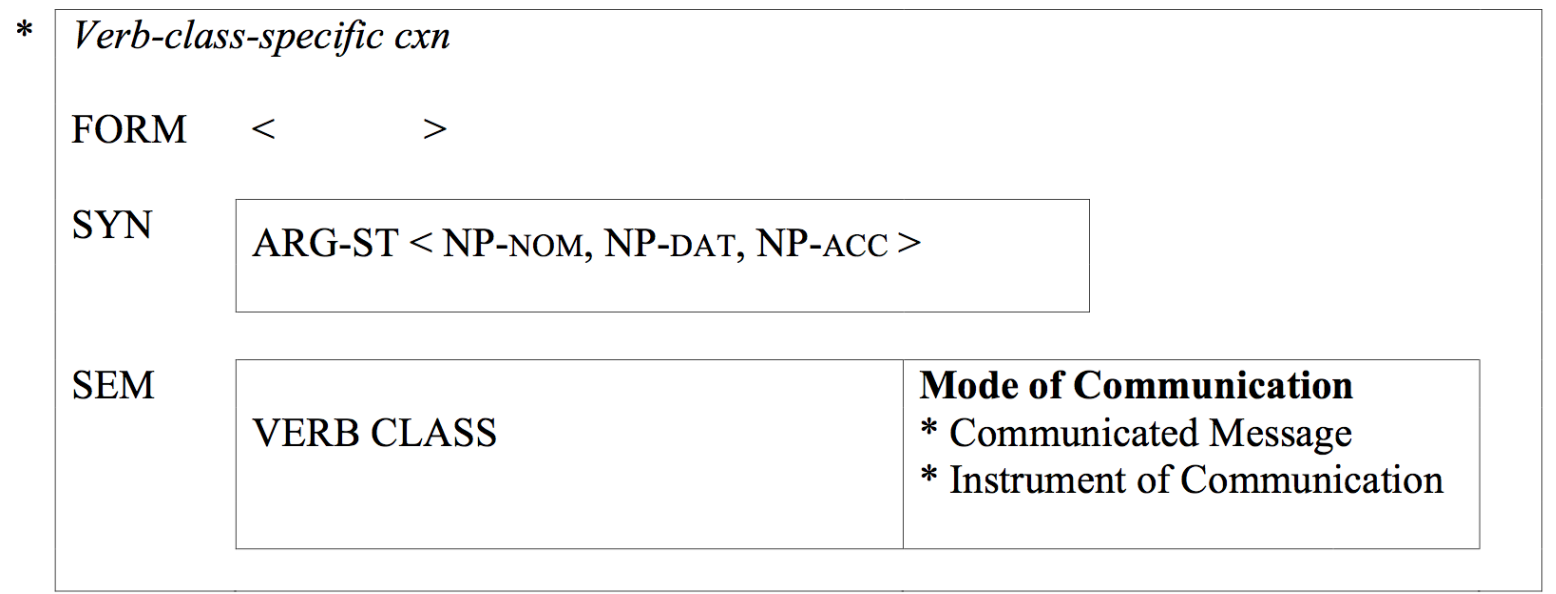

Figure 11: A reconstruction of the verb-class-specific construction "Mode of Communication" for Proto-Germanic

Taking our reconstruction one level higher, namely to verb-class-specific constructions, consider the reconstruction put forward in Figure 11. Here Communicated Message is now rendered, not as the highest level of the verb class as in Figure 10, but rather as a subclass 
in the even higher-level verb class of Mode of Communication, again defined through the SEM field.

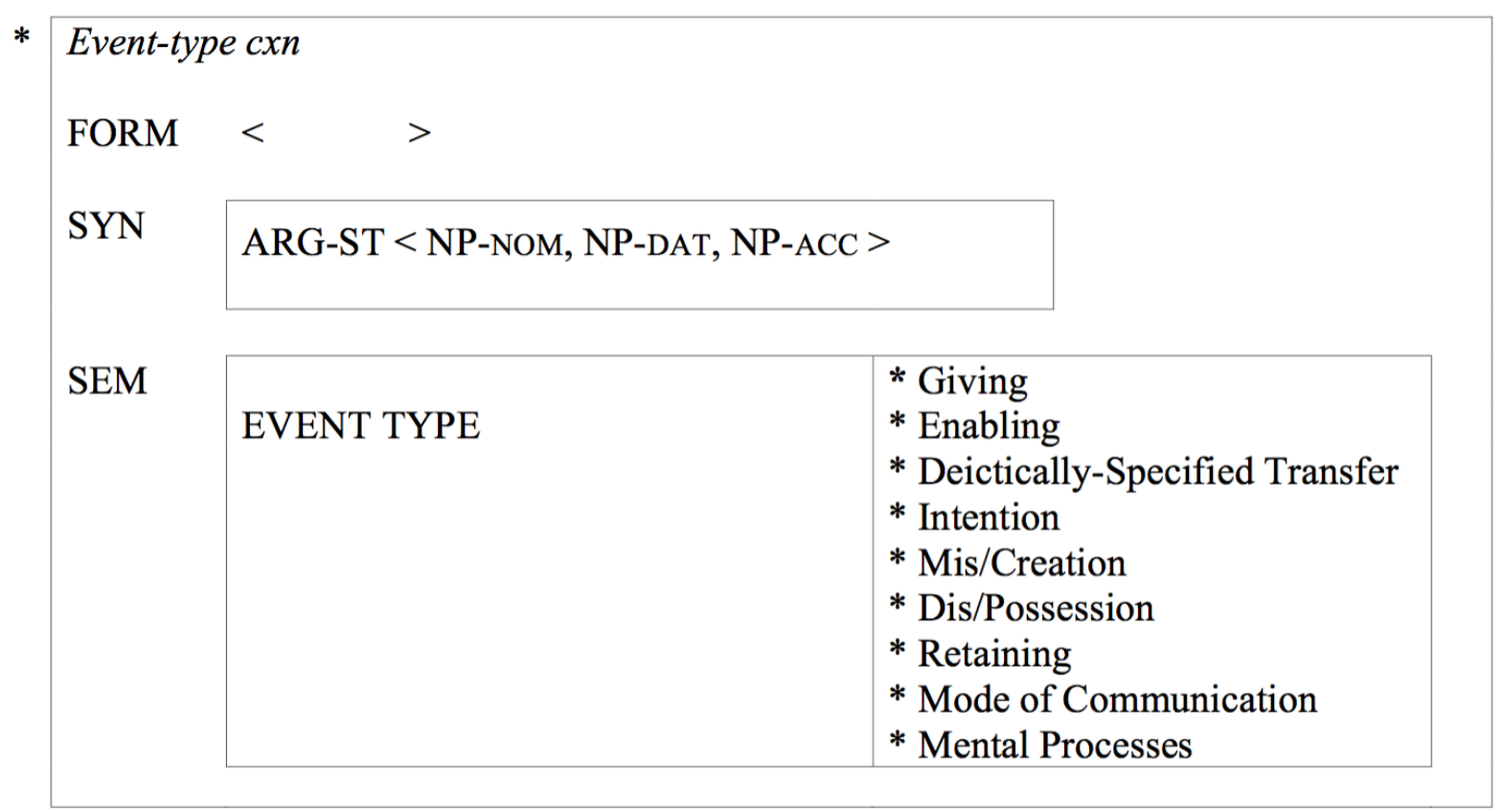

Figure 12: A reconstruction of the highly-schematic event-type construction for ProtoGermanic

Finally, we would like to propose a reconstruction of the high-schematic event-type construction for the ditransitive construction in Proto-Germanic, given in Figure 12. The SEM field specifies that this is an event-type construction and the event types are defined in terms of the conceptual domains corroborated for the ditransitive construction in the three early Germanic branches in Section 4 above. In that sense, this reconstruction is even more abstract than the verb-subclass-specific and verb-class-specific reconstructions above.

A question that now arises is whether the ditransitive construction in Proto-Germanic may have existed at an even higher level than the event-type level, namely at the highest most schematic level of [NOM-V-DAT-ACC]. At such a schematic level the semantics of the construction has been reduced to relational notions simply involving the most abstract relations between the participants. However, it is only justifiable to assume such a high level of schematicity for lexically open constructions (Barðdal 2008: 45-50, Barðdal 2011b). Our investigation into the Old English and Old Norse-Icelandic constructions has not suggested that the ditransitive in these languages may have an open verb slot which any verb in the language can instantiate. And the Gothic data are even less conclusive in this respect given the much smaller size of that corpus (hence the dotted lines at the highest level in Figure 7 above). On the contrary, the instantiations are limited to the conceptual domains listed in Figure 12, clearly demarcating the semantic boundaries of the ditransitive construction, not only for the three early Germanic languages investigated here, but also for Proto-Germanic.

To summarize the content of this section, we have put forward reconstructions for the ditransitive construction in Proto-Germanic at different levels of schematicity, ranging from the lowest most concrete verb-specific level to the highest and most schematic event-type level that may be posited for the ditransitive on the basis of the data presented in Section 4 above. On the assumption that constructions are psychologically real entities, all these levels must be assumed to have existed in the minds of speakers of Proto-Germanic. 


\section{Summary and Conclusions}

This article presents the first large-scale study of the Nom-Dat-Acc ditransitive construction in Proto-Germanic, as it rests on a thorough investigation of all three Germanic branches, East (Gothic), West (Old English) and North Germanic (Old Norse-Icelandic). As such, this article provides the first full account of the ditransitive construction in Gothic and the largest up-to-date collectanea in terms of type frequency for Old English and Old Norse-Icelandic.

On the basis of this comparison, we have have put forth a reconstruction of the ditransitive construction for Proto-Germanic at different levels of schematicity, including the verb-specific level, verb-subclass-specific level, verb-class-specific level, as well as the event-type level, defined by the nine conceptual domains involved in the semantic distribution of the construction. For this purpose, we have made use of the formal machinery of Construction Grammar, where syntactic objects are assumed to be form-meaning correspondences, as such qualifying as legitimate objects of the Comparative Method.

Our analysis of the Nom-Dat-Acc ditransitives in the early East, West and North Germanic languages reveals a schematically less constrained, and typologically enlarged, cognitive schema for the ditransitive construction in Proto-Germanic. This schema involves actual transfer but also integrates other notions like favors and assistance in general (benefactives) and their opposites (malefactives), which significantly contrasts with the current situation in the Germanic languages and English. These three major semantic fields, actual transfer, favors/assistance and disfavors/hindrance are further developed at the literal and metaphorical levels in the domains of Mode of Communication and Mental Processes. Additionally, room is made for other notions where there is no transfer involved, which happens for instance with verbs of owning, among others. Hence, the scope of the ditransitive construction in the early Germanic languages is more similar to the semantic scope of the ditransitive construction in the Standard Average European languages, being considerably broader in scope, as opposed to the narrow scope of the construction in Modern English. For the purpose of illustrating this graphically, we have made use of Malchukov, Haspelmath \& Comrie's (2007) layout, originally proposed on the basis of their typological data, and we have shown how their semantic map may be adapted to account for the complex conceptual scenario found in Proto-Germanic.

In terms of narrowly-defined semantic verb classes, we have demonstrated the validity of the proposals of Barðdal (2007) and Barðdal, Kristoffersen \& Sveen (2011) for Proto-Germanic, where considerably more narrowly defined semantic verb classes are found than in Modern English. We have also documented the existence of verbs of instrument of communication, which the previous literature has exclusively associated with modern technological advances. Other constructional changes are more subtle: the existence of verbs of transfer along a path in Proto-Germanic is in consonance with the situation in the modern Germanic languages but in contrast with Modern English. Similarly, verbs of owning, here documented in Old English and Old Icelandic, have been preserved in Modern Icelandic but are only marginally found in the other Germanic languages, like in German and English. Finally, verbs of choosing (a subclass of verbs of obtaining) were used ditransitively in the earliest documented periods of Germanic, a usage which is infelicitous in Modern English.

In terms of prototypical domains, we have largely validated Barðdal, Kristoffersen \& Sveen's (2011) proposal. However, the overall picture we have obtained is larger and slightly different, the most noticeable major constructional changes being the presence of verbs of miscreation and of dispossession. The first, verbs of cutting and killing, are unacknowledged in the Modern Germanic languages. The second, verbs of removal and spoliation, were already weakly attested during the late Modern English period but are now obsolete in English. Also, the scope of Enabling is considerably larger in the early Germanic languages than in Modern English, which can be seen, for instance, by the fact that some verbs currently belonging to Mental Processes, like forgive, belonged to the conceptual domain of Enabling in Old English. This explains the obfuscated anomaly that the mental state verb 'forgive' is used ditransitively in the modern Germanic languages. Returning to transfer, deictically-directed verbs of continuous motion may also specify circular motion schemata 
with verbs like 'wend' and 'turn', as well as specifying manner with verbs like 'drag' and 'carry', something that is infelicitous in Modern English.

Finally, by making use of the box formalism of Construction Grammar, we have operationalized the semantics of these verb classes into the meaning component for the corresponding syntactic reconstruction of the Nom-Dat-Acc ditransitive construction. We have shown that the ditransitive Nom-Dat-Acc construction clearly existed at a higher schematic level in the minds of Proto-Germanic speakers than in the minds of speakers of the modern Germanic languages, thus reconstructing for the first time in the literature constructions at such high levels of schematicity.

\section{Appendix: Ditransitive verbs across Conceptual Domains in Early Germanic}

\section{Domain 1: Verbs inherently signifying giving and delivering}

Gothic: giban ${ }^{1}$ 'to give', atgiban ${ }^{1}$ 'to give over, deliver', andsaljan 'to render honor, pay tribute to', gawadjon 'to pledge, betroth', ustiuhan 'to present', andstaldan 'to provide, furnish'; anafilhan 'to commit'; gadailjan 'to distribute', disdailjan 'to distribute, parcel out'; usgiban 'to give back, repay', usgildan 'to repay, requite'.

Old English: sellan ' to give', gesellan "to give, give up', ræcan 'to give, reach out', beweddian 'to betroth', gehalgian 'to consecrate, sanctify', fedan 'to nourish, sustain'; befeolan 'to bestow sth upon sb, commit to', betæcan 'to entrust, commit', befæstan 'to commend, commit'; dælan 'to distribute', todælan 'to distribute, divide', scirian 'to divide, allot', scrifan 'to decree, allot judgement'; agiefan 'to give in return, pay', agieldan 'to pay back, return', gieldan 'to pay, repay', forgieldan 'to repay, requite', gebetan 'to repair, compensate', sellan wip 'to sell'.

Old Norse-Icelandic: selja 'to give, sell', gefa 'to give', fá 'to give', rétta 'to hand', gifta 'to pledge, betroth', fæða 'to raise, bring up', skipa stað 'to give property (by official order)'; skipa e-m e-ð 'to assign sth to one', fela 'to entrust', fá e-m e-t at geyma 'to give into one's charge', bjóða e-m erendi 'to commit sth to one's charge'; deila 'to allot one sth, deal out to one', skera 'to cut, shape', byggja 'to parcel out'; gjalda 'to compensate, pay', bœta e-m e-t 'to compensate one for sth', launa 'to requite, repay, pay', gefa e-m e-t til e-s 'to give sb sth in return for sth, pay', göra tíund 'to pay tithes'.

\section{Domain 2: Enabling}

Gothic: giban 'to give', atgiban ${ }^{2}$ 'to give over, deliver', fragiban' 'to confer, bestow', fragiban ${ }^{2}$ 'to forgive', mipgaqiujan 'to give life to together with, raise up with'; afletan ${ }^{1}$ 'to leave, forsake', afletan ${ }^{2}$ 'to forgive', fraletan ${ }^{1}$ 'to set free, release', fraletan ${ }^{2}$ 'to forgive'; uslaubjan 'to give consent, permit'.

Old English: sellan 'to give, confer', gesellan 'to confer gratuitously the ownership of', giefan 'to give, confer', forgiefan ${ }^{1}$ 'to confer, allow', forgiefan ${ }^{2}$ 'to forgive, overlook', geunnan 'to grant', dihtan 'to appoint'; Iænan 'to lend, grant', gelænan 'to lend, lease', leon 'to lend, grant'; lætan 'to allow, permit', forlætan 'to let go, relinquish', alætan 'to forgive, pardon', forberan 'to forbear, endure'; Iyfan 'to give leave, allow', alyfan 'to give leave, grant', pafian 'to consent to, permit', gepafian 'to favor, support'.

Old Norse-Icelandic: gefa 'to confer, bestow', fyrirgefa 'to forgive', veita 'to grant, confer', veita e-m lið, 'to give one help, assist', veita e-m eina bæn 'to grant a request', gera gagn 'to do a favor', tjá 'to show, grant', tjá e-m góđvilja to 'show one a kindness', velja e-m gjafar 'to pick out gifts for someone', göra e-m kost 'to grant sb a choice', göra e-m lög 'to grant the law to one', líkna 'to show mercy, forgive', nýta 'to utilize'; Ijá 'to lend, grant'; láta 'to allow, permit'; leyfa 'to allow, permit'.

\section{Domain 3: Deictically Specified Transfer}

Gothic: gamipsandjan 'to send thither along', mipinsandjan 'to send thither along', atbairan 'to bring, lead', attiuhan 'to pull, draw'; wandjan 'to wend, turn'; gadragan 'to draw together'.

\footnotetext{
${ }^{1}$ The semicolon in bold separates the existing verb subclasses in each conceptual domain.
} 
Old English: sendan 'to send', beran 'to bear, carry', ætberan 'to bear away, bear forth', bringan 'to carry, bear', bringan offrunga 'to bring sb an offering', lædan 'to carry, bring forth', dragan 'to drag, pull'.

Old Norse-Icelandic: senda 'to send', gera orð 'to send a message', bera 'to carry, bring', bera e-m kveðju/orð/orðsending 'to bring one a greeting/word/message', fœra 'to bring, take', draga 'to drag, pull' .

\section{Domain 4: Intention}

Gothic: bileipan 'to leave, leave behind', galewjan 'to present, offer'; swaran 'to swear, take an oath', biswaran 'to put under oath'.

Old English: Iæfan 'to leave', beodan 'to offer', gebeodan 'to offer, propose', offrian 'to offer, sacrifice', geoffrian 'to offer, sacrifice', foresceowian 'to foresee, provide', leanian 'to reward, recompense', geleanian 'to reward, repay'; beweddian 'to pledge', behatan 'to promise, vow', swerian að(/as) 'to swear, make oath(s)', sculan 'to owe'.

Old Norse-Icelandic: leifa 'to leave', bjóđa 'to offer', launa 'to reward', œtla 'to intend', huga 'to make out, think out', segja sér e-ð af hendi 'to renounce sth'; sverja eið 'to swear, promise upon oath', borga 'to guarantee'.

\section{Domain 5: Creation, Miscreation}

Gothic: gawaurkjan 'to do, make', gataujan 'to do, make, produce', gatimrjan 'to build', gasatjan namna 'to surname'; manwjan 'to prepare, make ready', gasmeitan 'to spread, anoint', bismeitan 'besmear, anoint'; afwalwjan 'to roll away, remove by rolling', uslukan 'to unlock, open'; afslahan 'to strike off, cut off', afmaitan 'to chop off, cut off', gawaurkjan daupu 'to cause death', ufsneipan 'to kill, butcher'.

Old English: wyrcan 'to do, make', don 'to do, make', don teala 'to do good', timbrian 'to build, construct', getimbrian 'to build, construct', plantian 'to plant', siwian 'to sew', onsettan nama 'to surname', gesettan 'to set', gegeotan 'to cast', cennan 'to beget, conceive', acennan 'to bring forth, conceive', strienan 'to gain, beget'; gearwian 'to prepare, make ready', gegearwian 'to prepare, make ready', gearcian 'to prepare, procure', don gebeorscipe to make someone a feast'; ryman 'to clear, make room', awyltan 'to roll, roll away', openian 'to open, open up', ryman 'to make roomy, enlarge', ryman weg 'to clear, make way'; don lað 'to do harm', gesnipan 'to cut, cut off', ofslean 'to strike down, kill', ofaslean 'to kill, slay'; sirwan 'to prepare, attempt with craft'; belucan 'to close, prevent a passage through', forsettan weg 'to obstruct a path', fortynan weg 'to stop, hinder the way', fordician weg 'to obstruct, barricade, block up a path'.

Old Norse-Icelandic: setja 'to make, create', skera 'to cut, sew', timbra 'to carpenter', kenna 'to father', vinna e-m bót 'to do one good', göra gott 'to do good'; göra 'to do, prepare', klá 'to scratch, rub', temja sér e-t 'to exercise'; trođa sér gadd 'to tread'; gera e-m mein 'to cause someone harm, hurt', veita e-m áverka 'to inflict a wound on someone', vinna e-m illt 'to to do one harm', göra illt 'to do ill', göra e-m geig 'to work harm to one', vekja sér blóð 'to open a vein, let blood', veita e-m bana 'to cause death', vinna e-m bana 'to cause death to one, kill', ráda e-m bana 'to do to that, do away'.

\section{Domain 6: Possession, Obtaining and Dispossession}

Gothic: haban 'to have'; huzdjan 'to lay up treasure, hoard', gadragan 'to draw together, amass', niman 'to take, receive', franiman 'to acquire, take possession of', bugjian 'to buy, purchase'; afslaupjan 'to clip off, put off'.

Old English: habban 'to have', agan (refl.) 'to own, possess for oneself', sparian 'to spare'; gaderian 'to gather together, collect', goldhordian 'to hoard, lay up treasure', agnian 'to appropriate, seize', agnian land (refl.) 'to appropriate, claim land as one's own', geagnian 'to appropriate, seize', niman 'to take, receive', onfon 'to take, receive', begietan 'to get, obtain', findan 'to find', gemetan 'to find, find out', ceosan 'to choose, select', geceosan 'to elect, choose', bycgan 'to buy, acquire', geceapian 'to buy, purchase', gestrienan 'to obtain, acquire', earnian 'to earn, deserve'; abregdan 'to move quickly, suddenly or violently, remove', ætbregdan 'to take away, withdraw', beniman 'to take away, deprive', forstelan 'to steal with violence, rob', 
afyrran 'to remove, take away', tosecan 'to deprive', bewerian 'to keep something from a person, forbid'.

Old Norse-Icelandic: hafa 'to have', eiga sér e-t 'to have, possess something for oneself', spara sér e-t 'to save, spare something for oneself'; eigna e-m e-t 'to attribute property to one', eigna sér land 'to take land into one own's hands', helga sér land 'to appropriate land by performing sacred rites', skilja sér e-t 'to reserve to oneself', nema 'to take, take possession of', fá 'to get, get hold of', taka 'to take, seize', geta 'to get', finna 'to find', kjósa 'to choose', velja 'to choose, pick out', kaupa 'to buy', afla sér fjár ok fraegđar 'to earn oneself fame and wealth', sœkja 'to fetch', frelsa 'to free, secure a thing for one', nýta 'to utilize'; afsifja sér e-t 'to alienate from one's family', sitja e-m e-t 'to cut one off from'.

\section{Domain 7: Retaining}

Gothic: warjan 'to forbid', lagjan handau 'to lay, place hands on', ufhnaiwjan 'to put under, subdue'; pwahan 'to wash, bathe', uspwahan 'to wash, bathe', skalkinon 'to serve, be a slave', fastan 'to have in custody, keep'.

Old English: werian 'to keep off, keep sb from sth', bewerian 'to keep something from a person, forbid', warian 'to ward off', warnian 'to warn, caution', forbeodan 'to forbid, refuse', geteon wearne 'to give someone a denial/refusal', don yfel 'to do evil', don teonan 'to do wrong', đreatian 'to oppress, afflict', befeolan 'to dispose, importune', settan 'to set over, place', asettan 'to set, place', gesettan 'to set, fix', onsettan 'to impose'; gepwean 'to wash', hyrsumian 'to obey, serve', gehyrsumian 'to make obedient, bring into subjection', underðeodan 'to subject', ðeowian 'to serve', đegnian 'to serve, minister', byrelian 'to pour out, give to drink', ætfæstan 'to fasten, inflict on', læstan 'to perform, discharge a debt or duty', gelæstan 'to discharge an obligation', geđeodan 'to join, associate', sellan (fore)gislas 'to give hostages as security for the performance of a promise'.

Old Norse-Icelandic: verja e- $m$ e-t 'to guard a place, hold it against a comer', varða e-m $e-ð$ 'to defend', gera e-m óspekt 'to cause turmoil to somebody', setja lög 'to set laws', leiða 'to make someone dislike something', gera e-m skomm 'to bring dishonor on one', veita e-m vegskarð 'to inflict a flaw in sb's honor', gjalda e-m fjándskap 'to show ill-will towards one', vinna e-m úsœmd 'to bring shame, disgrace on one', gera $e-m$ illt 'to do evil', setja e-m e-t 'to submit to', veita e- $m$ atför/heimferð 'to make an expedition against one', bjóđa e-m ógn 'to affright, terrify', bjóđa e-m ójöfnuð 'to treat unfairly, oppress', bjóđa e-m rangt 'to treat one unjustly'; gera lotning 'pay homage', tjá e-m pjónustu 'to pay homage to', vinna e-m beinleika 'to do one service, attend on one as a guest', setja e-m gisla 'to put guards around sb', setja e-m skriftir 'to put sb up for confession', pola 'to endure, suffer'.

\section{Domain 8: Mode of Communication}

Gothic: qiban 'to say', fauraqiban 'to predict, foretell', rodjan 'to speak, tell', gateihan 'to tell, report', fauragateihan 'to foretell', kannjan 'to appraise of, inform of', gakannjan 'to announce, proclaim', merjan 'to proclaim', wailamerjan 'to praise, preach', spillon 'to announce, proclaim', ussakan 'to expound thoroughly or in detail', anainsakan 'to add by argumentation', andbindan 'to untie, explain', laisjan 'to teach', anabiudan 'to command, bid', augjan 'to put before the eyes, show', ataugjan 'to bring before the eyes, show', gabairhtjan 'to bring to light, show clearly', uslukan augona 'to unlock, open the eyes to someone', taiknjan 'to show, manifest'; gameljan 'to write'.

Old English: secgan 'to say, tell', secgan bigspell 'to tell a parable', asecgan 'to speak out, declare', cweđan 'to say, speak', tocweđan 'to say', cyðan 'to reveal, manifest', sprecan 'to speak', mapelian 'to speak, make a speech', tellan 'to tell, compute', clipian 'to call, address', togeclypian 'to call together, send forth', gecennan 'to declare, prove', bodian 'to announce, proclaim', bicnian 'to indicate, declare', gebicnian 'to indicate, tell', tacnian 'to indicate, point out', openian 'to disclose,

\footnotetext{
2 Three examples of ditransitive usages found in the conceptual domain of Mental Processes below, acknowledged in Bosworth \& Toller (1921), appear to be of Early Middle English ascription. These are mapelian 'speak', unnan god 'wish well' and unnan yfel 'wish evil'.
} 
manifest', geopenian 'to open, manifest', ætywan 'to show, reveal', reccan 'to explain, tell', reccan bigspell 'to tell a parable', reccan swefn 'to tell someone a dream', areccan 'to recount, tell', areccan bigspell 'to explain a parable', spellian 'to talk, relate', gewisian 'to teach, explain', Iæran 'to teach', beodan 'to command', bebeodan 'to command, order', acsian 'to ask', biddan 'to ask, entreat', gebiddan 'to ask for something for a person', abiddan 'to ask, pray to/for', andswarian 'to answer', andwyrdan 'to answer', pancian 'to thank, give thanks', don pancas 'to thank, give thanks', teon stale 'to accuse', ætwitan 'to reproach, blame', oðwitan 'to blame, reproach with', cennan 'to bring forth from the mind, prove', ontynan 'to open, reveal', atynan 'to open, reveal', onlucan 'to open, reveal', deman 'to adjudge', ætiewan 'to explain, show',_sweotolian 'to make clear or manifest, show', gesweotolian 'to make clear or manifest, show', iewan 'to show', ætiewan 'to show', æteowian 'to show', getacnian 'to show', tæcan 'to offer to view, present', betæcan 'to show, point out', wisian 'to show, direct'; writan 'to write', awritan 'to write down, compose', secgan $æ f e n l a c$ 'to recite the evening sacrifice psalm', singan 'to sing, recite', geærendian 'to go on an errand, intercede'.

Old Norse-Icelandic: kveđa 'to quoth, say', segja 'to tell', segja e-m leið 'to tell the way, pilot', telja 'to tell', spá e-m e-t 'to forecast, foretell', kunngera 'to make sth known to sb', bođa 'to preach', kenna 'to teach', bjóđa e-m erendi 'to order someone (on) an errand', biðja sér ölmusu 'to ask for alms', biðja (sér) konu 'to ask in marriage', pakka e- $m$ e-t 'to thank, give thanks', mæla sér e-t 'to claim for oneself, telja sér e-t 'to claim, reckon as one's property', festa trú 'to declare loyalty', gera sér gabb og gaman 'to make fun of', gefa sök 'to accuse', fá e-m sök, 'to charge one', leggja e-m e-t til ámælis/orðs 'to blame one for sth', velja e-m hæðilig ord, 'to speak ignominiously to (or of) one', afsegja sér e-t 'to resign, renounce', kenna 'to attribute', kynna e-m e-t 'to make known, communicate to one', dœma e-m e-t, 'to adjudge a thing to', dœma e-m dóm 'to deal out a sentence'; rísta e-m pursa-staff 'to carve/scratch a libelous rune against someone', gala 'to sing, chant', bera e-m vel (illa) söguna 'to give a favourable (unfavourable) account of one'.

\section{Domain 9: Mental Processes}

Gothic: rahnjan 'to reckon, count up', gamaudjan 'to call to mind, remind'.

Old English: witan 'to know, have knowledge of', hogian 'to think, intend', gemunan 'to remember, bear in mind', willan yfel 'to wish ill', unnan god 'to wish well', unnan yfel 'to wish evil/ill', unnan wean 'to wish woe, affliction', ofunnan 'to wish to deprive', pincan god 'to seem good', pincan yfel 'to seem bad'.

Old Norse-Icelandic: reikna 'to calculate, count', huga sér rád 'to think up a solution', hverfa e-m hugi 'to change sb's mind', hyggja e-m e-t 'to intend, to have in store for one', hyggja e-m gott 'to wish good for one', huga e-m e-t 'to think of, intend', vilja e$m$ gott 'to wish someone good', muna e-m e-t 'to remember sth against one', virða til punga 'to regard as demeaning', ætla 'to mean, suppose', ætla sér hóf 'to correctly estimate one's abilities'; ugga sér e-t 'to apprehend evil', unna e-m ást 'to bestow one's love on'.

\section{References}

Adler, Julia. 2011. Dative Alternations in German: The Argument Realization Options of Transfer Verbs. Hebrew University of Jerusalem PhD Dissertation.

Baker, Collin F., Charles J. Fillmore \& Beau Cronin. 2003. The Structure of the FrameNet Database. International Journal of Lexicography 16(3): 281-296.

Baker, Collin F., Charles J. Fillmore \& John B. Lowe. 1998. The Berkeley FrameNet project. COLING-ACL '98: Proceedings of the Conference, held at the University of Montreal, 86-90. Association for Computational Linguistics.

Barðdal, Jóhanna. 2004. The Semantics of the Impersonal Construction in Icelandic, German and Faroese: Beyond Thematic Roles. Focus on Germanic Typology, ed. by Werner Abraham, 105-137. Berlin: Akademie Verlag.

Barðdal, Jóhanna. 2006. Construction-Specific Properties of Syntactic Subjects in Icelandic and German. Cognitive Linguistics 17-1: 39-106. 
Barðdal, Jóhanna 2007. The Semantic and Lexical Range of the Ditransitive Construction in the History of (North) Germanic. Functions of Language 14(1):9-30.

Barðdal, Jóhanna. 2008. Productivity: Evidence from Case and Argument Structure in Icelandic. Amsterdam: John Benjamins.

Barðdal, Jóhanna. 2011a. The Rise of Dative Substitution in the History of Icelandic: A Diachronic Construction Grammar Account. Lingua 121(1): 60-79.

Barðdal, Jóhanna. 2011b. Lexical vs. Structural Case: A False Dichotomy. Morphology 21(3-4): 619-659.

Barðdal, Jóhanna. 2013. Construction-Based Historical-Comparative Reconstruction. The Oxford Handbook of Construction Grammar, ed. by Graeme Trousdale \& Thomas Hoffmann, 438-457. Oxford: Oxford University Press.

Barðdal, Jóhanna. 2014. Syntax and Syntactic Reconstruction. The Routledge Handbook of Historical Linguistics, ed. by Claire Bowern \& Bethwyn Evans, 343-373. London: Routledge.

Barðdal, Jóhanna, Valgerður Bjarnadóttir, Serena Danesi, Tonya Kim Dewey, Thórhallur Eythórsson, Chiara Fedriani \& Thomas Smitherman. 2013. The Story of 'Woe'. Journal of Indo-European Studies 41(3-4): 321-377.

Barðdal, Jóhanna \& Thórhallur Eythórsson. 2012a. Reconstructing Syntax: Construction Grammar and the Comparative Method. In Sign-Based Construction Grammar, 257308. Eds. Hans C. Boas \& Ivan A. Sag. Stanford: CSLI Publications.

Barðdal, Jóhanna \& Thórhallur Eythórsson. 2012b. "Hungering and Lusting for Women and Fleshly Delicacies": Reconstructing Grammatical Relations for Proto-Germanic. Transactions of the Philological Society 110(3): 363-393.

Barðdal, Jóhanna \& Thórhallur Eythórsson. 2019. How to Identify Cognates in Syntax: Taking Watkins' Legacy One Step Further. To appear in Reconstructing Syntax, ed. by Jóhanna Barðdal, Spike Gildea \& Eugenio R. Lujan. Leiden: Brill.

Barðdal, Jóhanna, Kristian E. Kristoffersen \& Andreas Sveen. 2011. West Scandinavian Ditransitives as a Family of Constructions: With a Special Attention to the Norwegian VREFL-NP Construction. Linguistics 49(1): 53-104.

Barðdal, Jóhanna \& Thomas Smitherman. 2013. The Quest for Cognates: A Reconstruction of Oblique Subject Constructions in Proto-Indo-European. Language Dynamics and Change 3(1): 28-67.

Barðdal, Jóhanna, Thomas Smitherman, Valgerður Bjarnadóttir, Serena Danesi, Gard B. Jenset \& Barbara McGillivray. 2012. Reconstructing Constructional Semantics: The Dative Subject Construction in Old Norse-Icelandic, Latin, Ancient Greek, Old Russian and Old Lithuanian. Studies in Language 36(3): 511-547.

Barðdal, Jóhanna \& Juan G. Vázquez-González. 2015. Reconstructing the Ditransitive Construction for Proto-Germanic. Paper delivered at the Workshop on Variation and Change in Dative and Ditransitive Constructions, Ghent University. February 24.

Bosworth, Joseph \& Thomas Northcote Toller. 1921. An Anglo-Saxon Dictionary. Oxford: Oxford University Press.

Bresnan, Joan \& Jennifer Hay. 2008. Gradient Grammar: An Effect of Animacy on the Syntax of give in New Zealand and American English. Lingua 18(2): 245-259.

Bert Cappelle. 2014. Conventional Combinations in Pockets of Productivity: English Resultatives and Dutch Ditransitives Expressing Excess. Extending the Scope of Construction Grammar, ed. by Ronny Boogaart, Timothy Colleman \& Gijsbert Rutten, 251-282. Berlin: De Gruyter Mouton.

Colleman, Timothy. 2002. De benefactieve dubbelobject-constructie in het 19de-eeuws Nederlands [The Benefactive Double Object Construction in 19th-Century Dutch]. De taal in Vlaanderen in de 19de eeuw: Historisch-sociolinguïstische onderzoekingen, ed. by R. Willemyns, 509-528. Gent: Koninklijke Academie voor Nederlandse Taal- en Letterkunde.

Colleman, Timothy. 2006. De Nederlandse datiefalternatie: een constructioneel en corpusgebaseerd onderzoek [The Dutch Dative Alternation: A Constructional and Corpus-Based Research]. Ghent University PhD Dissertation.

Colleman, Timothy. 2009. The Semantic Range of the Dutch Double Object Construction: A Collostructional Perspective. Constructions and Frames 1(2): 190-220. 
Colleman, Timothy. 2011. Ditransitive Verbs and the Ditransitive Construction: A Diachronic Perspective. Zeitschrift für Anglistik und Amerikanistik 59: 387-410.

Colleman, Timothy \& Bernard De Clerck. 2011. Constructional Semantics on the Move: On Semantic Specialization in the English Double Object Construction. Cognitive Linguistics 22(1): 183-209.

Croft, William, 2001. Radical Construction Grammar: Syntactic Theory in Typological Perspective. Oxford: Oxford University Press.

Croft, William. 2003. Lexical rules vs. constructions: A false dichotomy. Motivation in Language: Studies in Honour of Günter Radden, ed. by Hubert Cuyckens, Thomas Berg, René Dirven \& Klaus-Uwe Panther, 49-68. Amsterdam: John Benjamins.

Danesi, Serena, Cynthia A. Johnson \& Jóhanna Barðdal. 2017. Between the Historical Languages and the Reconstructed Language: An Alternative Approach to the Gerundive + "Dative of Agent" Construction in Indo-European. Indogermanische Forschungen 122: 143-188.

Danesi, Serena, Cynthia A. Johnson \& Jóhanna Barðdal. 2018. Where Does the Modality of Ancient Greek Modal Verbs Come From? The Relation between Modality and Oblique Case Marking. Journal of Greek Linguistics 18(1): 45-92.

De Cuypere, Ludovic. 2015a. A Multivariate Analysis of the Old English ACC+DAT Double Object Alternation. Corpus Linguistics and Linguistic Theory 11(2): 1-30.

De Cuypere, Ludovic. 2015b. The Old English to-dative Construction. English Language and Linguistics 19(1): 1-26.

Delorge, Martine \& Timothy Colleman. 2006. Constructions with Verbs of Dispossession in Dutch: A Corpus-Based Case Study. Studies van de BKL 1: 1-15.

Delorge, Martine \& Bernard De Clerck. 2007. A Contrastive and Corpus-Based Study of English and Dutch Provide-Verbs. Phrasis 48: 121-142.

De Vaere, Hilde, Ludovic De Cuypere \& Klaas Willems. 2018. Alternating Constructions with Ditransitive Geben in Present-Day German. Corpus Linguistics and Linguistic Theory, DOI: https://doi.org/10.1515/cllt-2017-0072.

Eythórsson, Thórhallur \& Jóhanna Barðdal. 2011. Die Konstruktionsgrammatik und die komparative Methode. In Indogermanistik und Linguistik im Dialog: Akten der XIII. Fachtagung der Indogermanischen Gesellschaft vom 21. bis 27. September 2008 in Salzburg, 148-156, ed. by Thomas Krisch \& Thomas Lindner. Wiesbaden: Reichert Verlag.

Eythórsson, Thórhallur \& Jóhanna Barðdal. 2016. Syntactic Reconstruction in IndoEuropean: The State of the Art. Franz Bopp and his Comparative Grammar Model (1816-2016), ed. by J. Gorrochategui, C. García Castillero \& J. M. Vallejo. A special monographic volume in Veleia 33: 83-102.

Fanego, Teresa. 2017. The Trolley Rumbled through the Tunnel: On the History of the English Intransitive Motion Construction. Folia Linguistica Historica 38: 29-73.

Fillmore, Charles J., Paul Kay \& Mary Kay O'Connor. 1988. Regularity and Idiomaticity in Grammatical Constructions: The Case of Let Alone. Language 64: 501-538.

Fried, Mirjam \& Jan-Ola Östman. 2005. Construction Grammar and Spoken Language: The Case of Pragmatic Particles. Journal of Pragmatics 37(11): 1752-1778.

Fritzner, Johan. 1886-1896. Ordbog over det gamle norske Sprog [Dictionary of the Old Norwegian Language]. Kristiania: Den norske Forlagsforening.

Geleyn, Tim. 2017. Syntactic Variation and Diachrony. The Case of the Dutch Dative Alternation. Corpus Linguistics and Linguistic Theory 13(1): 65-96.

Gerwin, Johanna. 2014. Ditransitives in British English Dialects. Berlin: De Gruyter Mouton.

Gildea, Spike. 1992. Comparative Cariban Morphosyntax: On the Genesis of Ergativity in Independent Clauses. University of Oregon PhD Dissertation.

Gildea, Spike. 1998. On Reconstructing Grammar: Comparative Cariban Morphosyntax. Oxford: Oxford University Press.

Gildea, Spike. 2000. On the Genesis of the Verb Phrase in Cariban Languages. In Reconstructing Grammar: Comparative Linguistics and Grammaticalization, 65-106, ed. by Spike Gildea, Amsterdam: John Benjamins.

Goldberg, Adele E. 1995. Constructions: A Construction Grammar Approach to Argument Structure. Chicago: University of Chicago Press. 
Goldberg, Adele E. 1997. The Relationships between Verbs and Constructions. Lexical and Syntactical Constructions and the Construction of Meaning, ed. by Marjolijn Verspoor, Kee Dong Lee \& Eve Sweetser, 383-298, Amsterdam: John Benjamins.

Green, D. H. 1998. Language and History in the Early Germanic World. Cambridge: Cambridge University Press.

Green, Georgia. M. 1974. Semantics and Syntactic Regularity. Bloomington, IN: Indiana University Press.

Gries, Stefan Th., Beate Hampe \& Doris Schönefeld. 2005. Converging Evidence: Bringing together Experimental and Corpus Data on the Association of Verbs and Constructions. Cognitive Linguistics 16(4): 635-676.

Gropen, Jess, Steven Pinker, Michelle Hollander, Richard Goldberg \& Ronald Wilson. 1989. The Learnability and Acquisition of the Dative Alternation in English. Language 65: 203257.

Grossman, Eitan \& Stéphane Polis. 2012. Navigating Polyfunctionality in the Lexicon: Semantic Maps and Ancient Egyptian Lexical Semantics Language. Lexical Semantics in Ancient Egyptian, ed. by Eitan Grossman, Stéphane Polis \& Jean Winand, 175-225. Hamburg: Kai Widmaier Verlag.

Haspelmath, Martin. 2004. On Directionality in Language Change with Particular Reference to Grammaticalization. Up and Down the Cline - The Nature of Grammaticalization, ed. by Fischer, Olga, Muriel Norde \& Harry Perridon, 17-47. Amsterdam: John Benjamins.

Harris, Alice C. 2008. Reconstruction in Syntax: Reconstruction of Patterns. Principles of Syntactic Reconstruction, ed. by Gisella Ferraresi \& Maria Goldbach, 73-95. Amsterdam: John Benjamins.

Harris, Alice C. \& Lyle Campbell. 1995. Historical Syntax in Cross-Linguistic Perspective. Cambridge: Cambridge University Press.

Haspelmath, Martin. 1999. External Possession in a European Areal Perspective. External Possession, ed. by Doris L. Payne \& Immanuel Barshi, 109-135. Amsterdam: John Benjamins.

Healey, Antonette diPaolo \& the DOE Project (eds.). 2009. The Dictionary of Old English: A$H$ on CD-ROM. Toronto: Pontifical Institute of Medieval Studies, University of Toronto.

Healey, Antonette diPaolo (ed.). 2000. The Dictionary of Old English Corpus in Electronic Form. Toronto: Pontifical Institute of Medieval Studies, University of Toronto.

Hoffmann, Sebastian \& Joybrato Mukherjee. 2007. Ditransitive Verbs in Indian English and British English: A Corpus-Linguistic study. Arbeiten aus Anglistik und Amerikanistik 32(1): 5-24.

Jackendoff, Ray. 1997. Twistin' the night away. Language 73: 534-559.

Kay, Paul \& Charles J. Fillmore. 1999. Grammatical Constructions and Linguistic Generalizations: The 'What's X doing Y?' Construction. Language 75: 1-33.

Kholodova, Alina, Caroline Rowland, Shanley Allen \& Michelle Peter. 2019. Ditransitive Syntactic Priming in a Biased Language: Investigating Abstract Representations over Development. To appear in Ditransitive Constructions in Germanic Languages: Diachronic and Synchronic Aspects, ed. by Timothy Colleman, Melanie Röthlisberger \& Eva Zehentner. Amsterdam: John Benjamins.

Kikusawa, Ritsuko. 2002. Proto Central Pacific Ergativity: Its Reconstruction and Development in the Fijian, Rotuman and Polynesian languages. Canberra: Pacific Linguistics.

Kikusawa, Ritsuko. 2003. The Development of Some Indonesian Pronominal Systems. Historical Linguistics 2001: Selected Papers from the 15th International Conference on Historical Linguistics, Melbourne, 13-17 August 2001, ed. by B. J. Blake, K. Burridge \& J. Taylor, 237-268. Amsterdam: John Benjamins.

Kittilä, Seppo. 2006. The Anomaly of the Verb 'Give' Explained by its High (Formal and Semantic) Transitivity. Linguistics 44(3): 569-612.

Klein, Jared S. 2010. Review of Principles of Reconstruction, ed. by G. Ferraresi \& M. Goldbach (2008). Language 86: 720-726.

Köbler, Gerhard. 1989. Gotisches Wörterbuch. Leiden: Brill.

Kroonen, Guus. 2013. Etymological Dictionary of Proto-Germanic. Leiden: Brill.

Lakoff, George. 1987. Women, Fire, and Dangerous Things: What Categories Reveal about the Mind. Chicago: University of Chicago Press. 
Levin, Beth. 1993. English verb classes and alternations: A preliminary investigation. Chicago: University of Chicago Press.

Lightfoot, David. 1979. Principles of Diachronic Syntax. Cambridge: Cambridge University Press.

Luján, Eugenio R. 2010. Semantic Maps and Word Formation: Agents, Instruments, and Related Semantic Roles. Linguistic Discovery 8(1): 162-175.

Luraghi, Silvia. 2014. Plotting Diachronic Semantic Maps. Perspectives on Semantic Roles, ed. by Silvia Luraghi \& Heiko Narrog, 99-150. Amsterdam: John Benjamins.

Malchukov, Andrej, Martin Haspelmath \& Bernard Comrie. 2007. Ditransitive constructions: A Typological Overview. First draft, Sept. 2007. Available at: https://www.keel.ut.ee/sites/default/files/www_ut/4-ditransitiveoverview.pdf.

Malchukov, Andrej, Martin Haspelmath \& Bernard Comrie. 2010. Ditransitive Constructions: A Typological Overview. Studies in Ditransitive Constructions: A Comparative Handbook, ed. by Andrej Malchukov, Martin Haspelmath \& Bernard Comrie, 1-64. Berlin: Mouton De Gruyter.

Meinunger, André. 2006. Remarks on the Projection of Dative Arguments in German. Datives and Other Cases, ed. by Daniel Hole, André Meinunger \& Werner Abraham, 79-101. Amsterdam: John Benjamins.

Michaelis, Laura A. 2010. Sign-Based Construction Grammar. The Oxford Handbook of Linguistic Analysis, ed. by Bernd Heine \& Heiko Narrog, 155-176. Oxford: Oxford University Press.

Michaelis, Laura A. 2012. Making the Case for Construction Grammar. Sign-Based Construction Grammar, ed. by Hans C. Boas \& Ivan A. Sag, 31-68. Stanford: CSLI Publications.

Michaelis, Laura A. \& Josef Ruppenhofer. 2001. Beyond Alternations: A Construction-Based Account of the Applicative Construction in German. Stanford: CSLI Publications.

Narrog, Heiko. 2010. A Diachronic Dimension in Maps of Case Functions. Linguistic Discovery 8(1): 233-254.

Narrog, Heiko \& Johan van der Auwera. 2011. Grammaticalization and Semantic maps. The Oxford Handbook of Grammaticalization, ed. by Heiko Narrog \& Bernd Heine, 318-327, Oxford: Oxford University Press.

Newman, John. 1996. Give: A Cognitive Linguistic Study. Berlin: Mouton de Gruyter.

Pinker, Steven. 1989. Learnability and Cognition: The Acquisition of Argument Structure. Cambridge, Mass: MIT Press.

Pokorny, Julius. 1959-1969. Indogermanisches etymologisches Wörterbuch. Bern: Francke.

Proost, Kristel. 2014. Ditransitive Transfer Constructions and their Prepositional Variants in German and Romanian: An Empirical Survey. Komplexe Argumentstrukturen, ed. by Ruxandra Cosma, Stefan Engelberg, Susan Schlotthauer, Speranta Stanescu \& Gisela Zifonun, 19-83. Berlin: De Gruyter.

Rauth, Philipp. 2016a. Die Rolle dialektaler Kasussysteme bei der Abfolge ditransitiver Objekte. Syntax aus Saarbrücker Sicht 1: Beiträge der SaRDiSTagung zur Dialektsyntax, ed. by Augustin Speyer \& Philipp Rauth, 109-135. Stuttgart: Steiner.

Rauth, Philip. 2016b. Graduelle Ditransitivität im Deutschen. Zeitschrift für germanistische Linguistik 44(2): 172-214.

Rohdenburg, Günter. 1995. Betrachtungen zum Auf- und Abstief einiger präpositionaler Konstruktionen im Englischen. NOWELE 26: 67-124.

Rohdenburg, Günter. 2007. Functional Constraints in Syntactic Change: The Rise and Fall of Prepositional Constructions in Early and Late Modern English. English Studies 88(2): 217-233.

Røreng, Anita. 2011. Die deutsche Doppelobjektkonstruktion: Eine korpusbasierte Untersuchung zur relativen Abfolge nominaler Akkusativ- und Dativobjekte im geschriebenen Deutsch. University of Troms $\varnothing \mathrm{PhD}$ Dissertation.

Sag, Ivan. 2012. Sign-Based Construction Grammar: An Informal Synopsis. Sign-Based Construction Grammar, ed. by Hans C. Boas \& Ivan A. Sag, 69-202. Stanford: CSLI Publications.

Siewierska, Anna \& Willem Hollmann. 2007. Ditransitive Clauses in English with Special Reference to Lancashire Dialect. Structural-Functional Studies in English Grammar: In 
Honour of Lachlan McKenzie, ed. by Michael Hannay \& Gerard J. Steen, 83-102. Amsterdam: John Benjamins.

De Smet, Hendrik. 2005. A Corpus of Late Modern English. ICAME Journal 29: 69-82.

Stefanowitsch, Anatol \& Stefan T. Gries. 2003. Collostructions: Investigating the Interaction of Words and Constructions. International Journal of Corpus Linguistics 8(2): 209-243.

Stefanowitsch, Anatol. 2006. Negative Evidence and the Raw Frequency Fallacy. Corpus Linguistics and Linguistic Theory 21: 61-77.

Streitberg, Wilhelm. 1960. Die gotische Bibel. I. Teil. 4th ed. Heidelberg: Carl Winter Universitätsverlag.

Traugott, Elizabeth Closs \& Graeme Trousdale. 2013. Constructionalization and Constructional Changes. Oxford: Oxford University Press.

Valdeson, Fredrik. 2019. Semantic Shifts in the Swedish Ditransitive Construction. 2019. Ditransitive Constructions in Germanic Languages: Diachronic and Synchronic Aspects, ed. by Timothy Colleman, Melanie Röthlisberger \& Eva Zehentner. Amsterdam: John Benjamins.

Vázquez-González, Juan G. 2013. The semantic and lexical range of the ditransitive construction in Old English. Paper delivered at the 2013 International Symposium on Verbs, Clauses and Constructions organized by the Functional Grammars Research Group. University of La Rioja, 27-29 November.

Vázquez-González, Juan G. 2014. Dative-Accusative ditransitive constructions in Skeat's edition of The Four Gospels in Anglo-Saxon, Northumbrian and Old Mercian versions. Paper delivered at the 2014 International Symposium on Verbs, Clauses and Constructions, organized by the Functional Grammars Research Group, University of La Rioja, 22-24 October.

Watkins, Calvert. 1976. Towards Proto-Indo-European Syntax: Problems and Pseudoproblems. Papers from the Parasession on Diachronic Syntax, ed. by Sanford B. Steever, Carol A. Walker \& Salokoko S. Mufwene, 306-326. Chicago: Chicago Linguistic Society.

Webelhuth, Gert \& Clare J. Danneberg. 2006. Southern American English Personal Datives: The Theoretical Significance of Dialectal Variation. American Speech 81(1): 31-55.

Willis, David. 2011. Reconstructing Last Week's Weather: Syntactic Reconstruction and Brythonic Free Relatives. Journal of Linguistics 47(2): 407-446.

Winter, Werner. 1984. Reconstructional Comparative Linguistics and the Reconstruction of the Syntax of Undocumented Stages in the Development of Languages and Language Families. Historical Syntax, ed. by J. Fisiak, 613-625. The Hague: Mouton.

Yáñez-Bouza, Nuria \& David Denison. 2015. Which Comes First in the Double Object Construction? English Language and Linguistics 19(2): 247-268.

Yáñez-Bouza, Nuria. 2016. May Depend on Me Sending It You: Double Objects in Early Grammars. Journal of English Linguistics 44(2): 138-161.

Zehentner, Eva. 2016. On Competition and Cooperation in Middle English Ditransitives. Vienna: University of Vienna Ph.D. Dissertation.

Zehentner, Eva. 2018. Ditransitives in Middle English: On Semantic Specialisation and the Rise of the Dative Alternation. English Language and Linguistics 22(1): 149-175. 